\title{
UJI KINERJA PENGOLAHAN AIR SIAP MINUM DENGAN PROSES BIOFILTRASI, ULTRAFILTRASI DAN REVERSE OSMOSIS (RO) DENGAN AIR BAKU AIR SUNGAI
}

\author{
Nusa Idaman Said \\ Pusat Teknologi Lingkungan, BPPTeknologi \\ JI. MH. Thamrin No. 8 Jakarta Pusat
}

\begin{abstract}
Water is a very basic need for humans, especially for cooking and drinking. With the rapid growth of population in particular need of clean water for the community also increased in numbers. The problem is with the poor quality of raw water for drinking water, then in addition to expanding its production costs, the result is often less good. One of the problems or issues that are often found in drinking water in the world these days that is the emergence of compounds called Trihalomethanes or THMs abbreviated, as a side effect of the disinfection process with a chlorine gas or hypochlorite compounds.

Currently, to removal organic pollutants, ammonia, detergents, odor and other micro pollutants in drinking water, PAM is usually used by the process of manufacturing processes using adsorbsi Powder Active Carbon Adsorption, continued with physicals processing is the process of coagulation, flocculation, sedimentation and disinfection with chlorine. With increasingly high prices of powdered activated carbon, coagulant and flocculant chemicals, then the cost of treating drinking water to be increasing.

To solve the problem above, one alternative is to develop clean water treatment technologies using a combination of biofiltration and ultrafiltration process, and to produce drinking water to proceed with processing using the process of reverse osmosis. Within the combination of biofiltration, ultrafiltration and reverse osmosis processes to treat the river water can be produced the drinking water with a very good quality without the use of chemicals for coagulation-flocculation process, and operational costs are relatively low.
\end{abstract}

Key words : Air siap minum, biofiltrasi, ultrafiltrasi, reverse osmosis

\section{PENDAHULUAN}

\subsection{Latar Belakang}

sumber air baku yang tercemar baik secara alami ataupun oleh buangan akibat aktifitas kegiatan manusia misalnya buangan rumah tangga maupun industri adalah penyebab terbentuknya senyawa trihalometanes (THMs), baik secara langsung atau tidak langsung. Senyawa precursors trihalomethane adalah Senyawa-senyawa yang secara potensial dapat menyebabkan terjadinya THMs. Salah satu precursor THMs adalah senyawa humus (Humic and Fulvic Substances) yang secara alami terbentuk akibat proses pelapukan daun-daun yang gugur atau sisa tumbuh-tumbuhan yang telah mati oleh aktifitas mikroorganisme. Air limpasan hujan (Run Off) membawa senyawa humus dari daerah hutan atau pertanian, kemudian air limpasan tersebut masuk ke sungai pada bagian hulu, kemudian akan terbawa ke bagian hilir. Di samping itu, air limbah yang berasal dari buangan domestik maupun industri sebagian diolah di pusat pengolahan limbah dan sebagian lagi yang tidak terolah masuk ke badan sungai. Air limbah baik domestik maupun industri mengandung zat organik yang besar.

Air sungai yang mengandung precursor THMs ini, kemudian diolah untuk dijadikan air minum masyarakat di daerah hilir. Kemudian Senyawa precursor THMs tersebut bereaksi dengan senyawa khlor yang digunakan untuk proses disinfeksi sehingga terbentuklah senyawa trihalomethanes dan senyawa halogen organik lainnya (JICA : "Water Supply Engineering VOL.I").

Selain itu, dengan semakin besarnya kandungan ammonia dalam air baku maka ammonia akan bereaksi dengan khlor membentuk senyawa khloramine yang mempunyai daya disinfeksi yang lebih rendah. Sebagai akibatnya konsumsi senyawa khlor yang digunakan akan bertambah besar, dan dengan semakin besarnya konsentrasi khlor yang digunakan maka kemungkinan akan terbentuknya THMs juga semakin besar. Dengan semakin besarnya konsentrasi senyawa amoniak dalam air baku, maka amoniak akan bereaksi 
dengan khlor menjadi khloramine yang daya desinfeksinya lebih lemah. Hal ini akan mengakibatkan konsumsi khlor akan menjadi lebih besar sehingga biaya operasi menjadi lebih tinggi.

Saat ini, untuk menghilangan polutan organik, amoniak, deterjen, bau dan polutan mikro lainnya di dalam air minum, PAM biasanya menggunakan proses pengolahan dengan proses adsorbsi dengan menggunakan Karbon Aktif Bubuk, dilanjutkan dengan pengolahan secara fisika yaitu dengan proses koagulasi, flokulasi, sedimentasi serta disinfeksi dengan khlorine. Dengan semakin mahalnya harga karbon aktif bubuk serta bahan kimia untuk kogulan dan flokulan, maka biaya pengolahan air minum menjadi menjadi semakin meningkat. Untuk menanggulangi masalah tersebut diatas, salah satu pemecahannya adalah dengan mengembangkan teknologi pengolahan air bersih menggunakan kombinasi proses biolfiltrasi dan proses ultrafiltrasi.

Untuk mengurangi kadar senyawa organik, deterjen dan amoniak di dalam air baku air minum maka air sungai harus diolah terlebih dahulu melalui suatu pengolahan pendahuluan sebelum masuk ke unit pengolahan. Salah satu alternatif yakni menggunakan proses biologis dengan sistem biofilter tercelup yang diisi dengan media penyangga dari bahan plastik tipe sarang tawon. Selanjutnya dilakukan pengolahan lanjutan dengan teknologi ultrafiltrasi yang dapat menyaring partikel dengan ukuran 0,01 mikron.

Dengan sistem kombinasi biofiltrasi dan ultrafiltrasi mempunyai beberapa kelebihan antara lain :

- Penggunaan proses biofiltrasi dapat menghilangkan senyawa polutan yang tidak bisa dihilangkan dengan proses konvensional misalnya, zat organik, amoniak, deterjen, pestisida, dll. Senyawa tersebut dapat diuraikan dengan proses biologis secara alami (natural).

- Tanpa menggunakan bahan koagulan dan flokulan. Dalam hal ini bahan yang digunakan hanya larutan kaporit untuk mendapatkan konsentrasi sisa klor yang cukup agar tidak terjadi rekontaminasi.

- Dengan proses ultra filtrasi dapat dihasilkan air olahan dengan kualitas yang sangat baik dan stabil.

- Bentuknya lebih kompak sehingga luas area yang dibutuhkan lebih kecil.

- Sangat fleksibel jika ada penambahan kapasitas.

Teknologi pengolahan air sistem osmosa balik (reverse osmosis) banyak dipakai di beberapa negara seperti Amerika, Jepang, Jerman dan Arab. Teknologi ini banyak dipakai untuk memasok kebutuhan air tawar bagi kota-

kota tepi pantai yang langka sumber air tawarnya.

Keunggulan teknologi membran osmosa balik adalah kecepatannya dalam memproduksi air, karena menggunakan tenaga pompa, sedangkan kelemahannya adalah penyumbatan pada selaput membran oleh bakteri dan kerak kapur atau fosfat yang umum terdapat dalam air payau. Untuk mengatasi kelemahan pada unit pengolah air osmosa balik selalu dilengkapi dengan unit anti pengerakkan dan anti penyumbatan oleh bakteri. Sistem membran reverse yang dipakai dapat berupa spiral wound. Membran ini mampu menurunkan kadar garam hingga $95-98 \%$. Air hasil olahan sudah bebas dari bakteri dan dapat langsung diminum.

Dengan menggunakan kombinasi proses biofiltrasi, ultrafiltrasi dan reverse osmosis untuk mengolah air sungai dapat dihasilkan air olahan air siap minum dengan kualitas yang sangat baik tanpa menggunakan bahan kimia untuk proses koagulasi-flokulasi dengan biaya operasional yang relatif rendah.

\subsection{Tujuan}

Pembangunan percontohan (pilot plant) unit pengolahan air sungai menjadi air siap minum dengan kombinasi proses biofiltrasi, ultrafiltrasi dan reverse osmosis (RO) serta serta uji performance pengoperasian alat.

\subsection{Metodologi}

Metodologi penelitian meliputi :

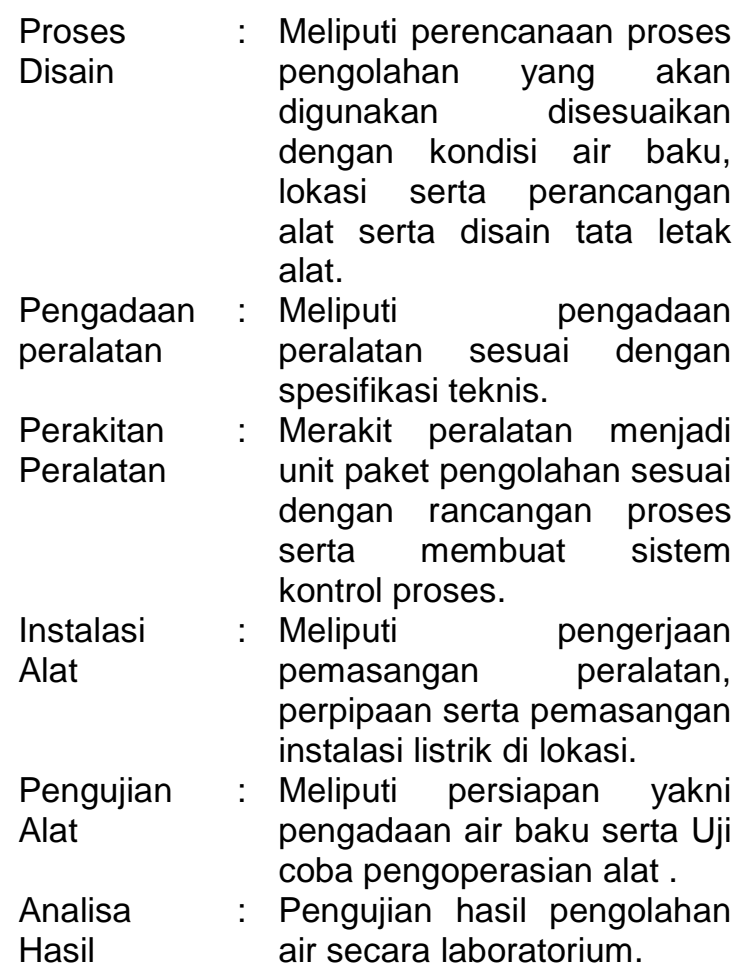




\subsection{Lokasi Penelitian}

Lokasi kegiatan pembangunan percontohan unit pengolahan air sungai menjadi air siap minum adalah di Pesantren Suka Hideung, Kabupaten Tasikmalaya, Propinsi Jawa Barat.

\section{TINJAUAN PUSTAKA}

\subsection{Mekanisme Penguraian Senyawa Polutan Di Dalam Proses Biofiltrasi}

Di dalam reaktor biofilter, mikroorganisme tumbuh melapisi keseluruhan permukaan media. Pada saat operasi, air yang mengandung senyawa polutan mengalir melalui celah media dan kontak langsung dengan lapisan massa mikroba (biofilm). Biofim yang terbentuk pada lapisan atas media dinamakan zoogleal film, yang terdiri dari bakteri, fungi, alga, protozoa mengatakan bahwa sel bakterilah yang paling berperan dan banyak dipakai secara luas di dalam proses pengolahan air buangan, sehingga struktur sel mikroorganisme lainnya dapat dianggap sama dengan bakteri ${ }^{10)}$.

Proses yang terjadi pada pembentukan biofilm pada air limbah sama dengan yang terjadi di lingkungan alami. Mikroorganisme yang ada pada biofilm akam mendegradasi senyawa organik yang ada di dalam air. Lapisan biofilm yang semakin tebal akan mengakibatkan berkurangnya difusi oksigen ke lapisan biofilm yang dibawahnya hal ini mengakibatkan terciptanya lingkungan anaerob pada lapisan biofilm bagian atas ${ }^{10}$ ). Mekanisme yang terjadi pada reaktor melekat diam terendam adalah ${ }^{5)}$ :

- Transportasi dan adsopsi zat organik dan nutrien dari fasa liquid ke fasa biofilm

- Transportasi mikroorganisme dari fasa liquid ke fasa biofilm

- Adsorpsi mikroorganisme yang terjadi dalam lapisan biofilm

- Reaksi metabolisme mikroorganisme yang terjadi dalam lapisan biofilm, memungkinkan terjadinya mekanisme pertumbuhan, pemeliharaan, kematian dan lysis sel.

- Attachment dari sel, yaitu pada saat lapisan biofilm mulai terbentuk dan terakumulasi secara kontinu dan gradual pada lapisan biofilm.

- Mekanisme pelepasan (detachment biofilm) dan produk lainnya (by product).

Proses awal pertumbuhan mikroba dan pembentukan lapisan film pada media membutuhkan waktu beberapa minggu, yang dikenal dengan "proses pematangan". Pada awalnya tingkat efisiensi penjernihan sangat rendah yang kemudian akan mengalami peningkatan dengan terbentuknya lapisan film ${ }^{7)}$
Pertumbuhan mikrooorganisme akan terus berlangsung pada slime yang sudah terbentuk sehingga ketebalan slime bertambah. Difusi makanan dan $\mathrm{O}_{2}$ akan berlangsung sampai ketebalan maksimum. Pada kondisi ini, makanan dan $\mathrm{O}_{2}$ tidak mampu lagi mencapai permukaan padat atau bagian terjauh dari fase cair. Hal ini menyebabkan lapisan biomassa akan terbagi menjadi dua bagian, yaitu lapisan aerob dan lapisan anaerob. Jika lapisan biofilm bertambah tebal maka daya lekat mikroorganisme terhadap media penyangga tidak akan kuat menahan gaya berat lapisan biofilm dan akan terjadi pengelupasan lapisan biomassa. Koloni mikroorganisme yang baru sebagai proses pembentukan lapisan biofilm akan terbentuk pada bagian yang terkelupas ini. Pengelupasan dapat juga terjadi karena pengikisan berlebihan cairan yang mengalir melalui biofilm. Mekanisme proses yang terjadi pada sistem biofilter secara sederhana dapat ditunjukkan seperti pada Gambar 16).

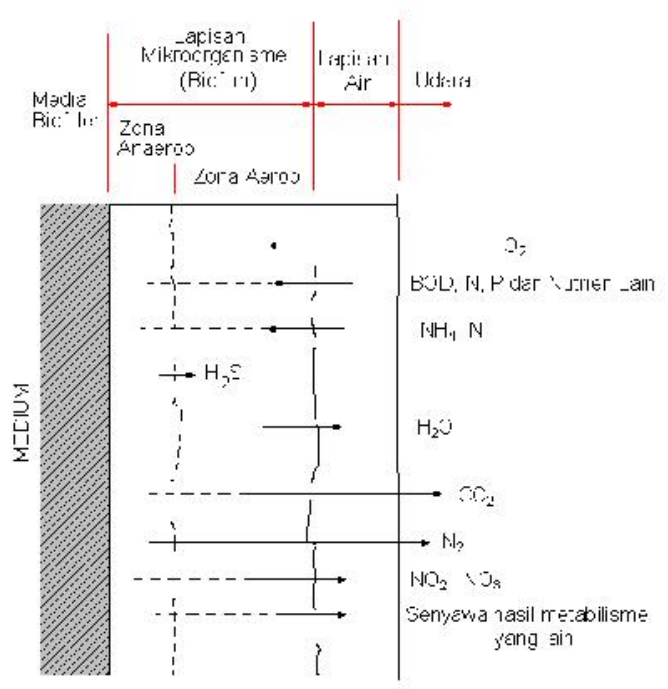

Gambar 1 : Mekanisme proses di dalam sistem biofilm

Pada proses aerobik efisiensi akan menurun dengan bertambahnya lapisan maksimum dan semakin tebalnya lapisan anaerob. Walaupun lapisan biomassa mempunyai ketebalan beberapa milimeter tetapi hanya lapisan luar setebal 0,05-0,15 mm yang merupakan lapisan aerob. Hasil penelitian yang telah dilakukan sebelumnya menegaskan bahwa penghilangan substrat oleh lapisan mikroba akan bertambah secara linier dengan bertambahnya ketebalan film sampai dengan ketebalan maksimum, penghilangan tetap konstan dengan bertambahnya ketebalan lebih lanjut 11). Ketebalan lapisan aerob diperkirakan antara $0,06-2 \mathrm{~mm}$. Ketebalan kritis berkisar antara 0,07 - 0,15 $\mathrm{mm}$ yang tergantung pada konsentrasi substrat ${ }^{11)}$. 


\subsection{Teknologi Membrane di Dalam Pengolahan Air}

Perkembangan teknologi dalam pengolahan air telah berkembang demikian pesatnya, yang mana diharapkan dapat menjadi jawaban untuk sebagian dari permasalahan yang ada dalam pengolahan air bersih. Salah satu teknologi yang dikembangkan adalah teknologi penyaringan atau filtrasi dengan menggunakan membran.

Teknologi menggunakan membran sebenarnya bukanlah suatu teknologi yang baru ditemukan, karena membran itu sendiri telah digunakan semenjak lebih dari 50 tahun yang lalu. Adapun jenis membran yang tersedia saat ini dibagi menjadi 4 kelompok besar disesuaikan dengan ukuran dari tingkat penyaringan atau sering disebut dengan istilah 'Filtration degree', Tingkat-tingkat penyaringan yang dimaksud adalah sebagai berikut 9) :

- Mikro Filtrasi (Micro Filtration ,MF).

- Ultrafiltrasi (Ultra Filtration,UF).

- Nano Filtrasi (Nano Filtration, NF).

- Osmosis Balik (Reverse Osmosis, RO).

Distribusi ukuran partikel yang dapat dipisahkan sesuai dengan tingkatan proses filtrasi dapat dilihat pada Gambar 2.

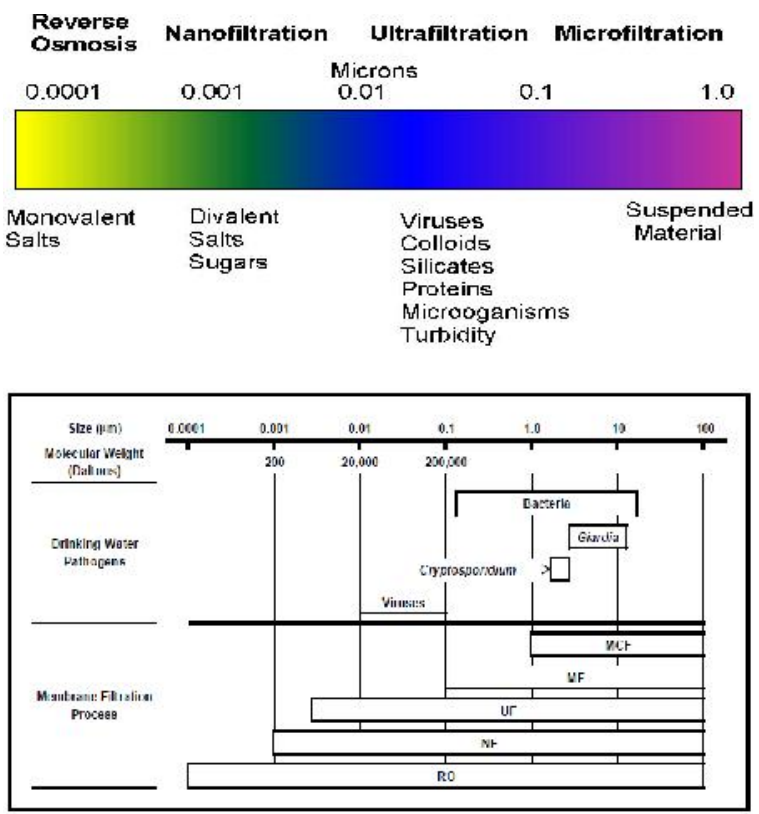

Gambar 2 : Distribusi ukuran partikel yang dapat dipisahkan sesuai dengan tingkatan proses filtrasi.

Selain ukuran pori, membran juga dikelompokkan berdasarkan besarnya berat molekul partikel kotoran yang dapat dipisahkan. Batas berat molekul yang dapat dipisahkan oleh suatu membran disebut batas berat molekul membran.
Batas berat molekul membran (molecular weight cutoff, MWCO) adalah ukuran dari karakteristik pemisahan dari suatu membran dalam istilah berat atom (massa), sebagai lawan dari ukuran pori-pori, biasanya diukur dalam Dalton. Satu Dalton adalah unit massa yang besarnya sama dengan $1 / 12$ massa atom karbon-12 (yaitu satu satuan massa atom (atomic mass unit, amu) biasanya digunakan sebagai satuan untuk mengukur batas berat molekul (MWCO) yang dapat dipisahkan oleh membran ultrafiltrasi (UF), membran nano filtration (NF) atau membran reverse osmosis (RO). Ukuran diameter pori dan batas berat molekul yang dapat dipisahkan oleh beberapa jenis membran dapat dilihat pada Tabel 1.

Tabel 1 : Ukuran diameter pori dan batas berat molekul yang dapat dipisahkan oleh beberapa jenis membran.

\begin{tabular}{|l|c|c|}
\hline Tipe Filtrasi & Ukuran Partikel & $\begin{array}{c}\text { Berat Molekul } \\
\text { (Dalton) }\end{array}$ \\
\hline Mikro Filtrasi & $\geq 0,1 \mu \mathrm{m}$ & $\geq 500.000$ \\
\hline Ultra Filtrasi & $0,01-0,1 \mu \mathrm{m}$ & $1000-500.000$ \\
\hline Nano Filtrasi & $0,001-0,01 \mu \mathrm{m}$ & $100-1000$ \\
\hline $\begin{array}{l}\text { Reverse } \\
\text { Osmosis }\end{array}$ & $\leq 0,001 \mu \mathrm{m}$ & $\leq 100$ \\
\hline
\end{tabular}

Sesuai dengan nama dan tingkatan dari tipe filtrasi diharapkan akan didapatkan air olahan dengan tingkat kualitas tertentu pula. Misalnya dengan menggunakan proses penyaringan ultra filtrasi (UF) dengan derajad penyaringan sekitar 0,1 sampai 0,01 micron, diharapkan sebagian besar dari padatan tersuspensi (suspended material) akan tersaring. Dengan menggunakan proses penyaringan osmosis balik (reverse osmosis, RO) dapat digunakan untuk mengolah air laut menjadi air tawar.

\subsubsection{Mikro Filtrasi}

Mikro filtrasi menggunakan membran mikroporous yang mempunyai ukuran pori efektif berkisar antara 0,07 - 1,3 $\mu \mathrm{m}$ (mikron), dan umumnya mempunyai ukuran pori aktual 0,45 $\mu \mathrm{m}{ }^{3)}$. Ukuran partikel yang dapat dihilangkan dengan proses mikro filtrasi berkisar antara 0.05 sampai $1 \mu \mathrm{m}$. Aliran melalui membran mikroporus dapat terjadi dengan menggunakan yang tekanan rendah, tetapi umumnya untuk aplikasi pengolahan air minum atau air limbah dilakukan dengan memberikan sedikit tekanan untuk meningkatkan produksi (fluks). Membran mikro filtrasi dapat menyaring atau menghilangkan partikel dengan ukuran sampai $0,1-0,2 \mu \mathrm{m}$. Dalam hal ini mikro filtrasi dapat 
digunakan untuk menghilangkan kekeruhan, alga, bacteria, cysta giardia, oocysta cryptosporodium dan seluruh material padatan. Mikro fltrasi sering juga digunakan untuk menghilangkan padatan tersuspensi atau koloid di dalam air limbah.

\subsubsection{Ultrafilrasi}

Ultrafiltrasi (UF) merupakan proses pemisahan menggunakan membran dengan ukuran pori-pori berkisar antara 0,1-0,001 $\mu \mathrm{m}$ (mikron). Biasanya, membran UF akan menghilangkan kotoran dari zat yang mempunyai berat molekul tinggi, material koloid, serta molekul polimer organik atau anorganik. Zat organik dengan berat molekul rendah dan ion ion seperti natrium, kalsium, magnesium klorida, serta sulfat tidak dapat dipisahkan oleh Membran UF. Karena hanya zat dengan berat molekul tinggi yang dapat dihilangkan atau dipisahkan, maka perbedaan tekanan osmotik di permukaan Membrane UF diabaikan.

Tekanan operasi rendah sehingga cukup untuk mencapai tingkat fluks yang tinggi dari membran ultrafiltrasi. Fluks membran UF didefinisikan sebagai jumlah air yang disaring atau diproduksi per satuan luas permukaan membran per satuan waktu. Umumnya fluks dinyatakan sebagai galon per meter persegi per hari (GFD) atau sebagai meter kubik per meter persegi per hari. Membran ultrafiltrasi (UF) dapat memiliki fluks sangat tinggi tetapi dalam banyak aplikasi praktis fluks bervariasi antara 50 sampai 200 GFD pada tekanan operasi sekitar 50 psig. Sedangkan, membran reverse osmosis (RO) hanya memproduksi antara 10-30 GFD pada 200-400 psig.

Ultrafiltrasi, seperti reverse osmosis, adalah proses pemisahan secara aliran lintas (cross-flow). Air yang akan diolah dialirkan secara tangensial ke sepanjang permukaan membran, sehingga menghasilkan dua aliran. Aliran air yang yang masuk dan meresap melalui membran disebut aliran air olahan (permeate). Jumlah dan kualitas air olahan akan tergantung pada karakteristik membran, kondisi operasi, serta kualitas air bakunya. Aliran lainnnya yakitu aliran air buangan (reject) atau disebut concentrate, dimana di dalam aliran air buangan mengadung zat atau kotoran yang telah dipisahkan oleh membran sehingga konsentrasinya menjadi lebih pekat. Oleh karena itu di dalam pemisahan secara aliran silang (cross-flow), membran itu sendiri tidak bertindak sebagai kolektor ion, molekul, atau koloid tetapi hanya bertindak sebagai penghalang.

$\mathrm{Di}$ dalam proses penyaringan dengan menggunakan filter konvensional, media penyaring atau filter cartridge, hanya menghilangkan padatan tersuspensi dengan menjebak kotoran dalam pori-pori media filter. Oleh karena itu filter ini bertindak sebagai deposit dari padatan tersuspensi dan harus sering dibersihkan atau diganti. Filter konvensional umumnya digunakan untuk pengoalahan awal sebelum proses pengolahan dengan sistem membran, yaitu untuk menghilangkan padatan tersuspensi yang relatif besar, sedangkan proses penyaringan dengan membran digunakan untuk menghilangkan partikel dan padatan terlarut.

Di dalam proses ultrafiltrasi, untuk beberapa aplikasi, tidak menggunakan filtrasi awal (prefilter) sehinnga modul ultrafiltrasi digunakan untuk memisahkan padatan tersuspensi atau material emulsi koloid. Berbagai bahan telah digunakan untuk membran ultrafiltrasi secara komersial, tetapi yang paling banyak dipakai adalah polysulfone dan selulosa asetat.

\subsubsection{Nano Filtrasi(NF)}

Nano berarti satu per milyar. Satu nanometer $(1 \mathrm{~nm})$ sama dengan $10^{-9} \mathrm{~m}=10^{-3} \mu \mathrm{m}$ (mikron). Nanofiltration (NF) adalah filtrasi membran cross-flow. Dalam air yang mengandung campuran beberpa jenis ion, ion monovalen cenderung menembus (melewati) membran sedangkan jenis ion divalen atau multivalent sangat mungkin akan dipisahkan pada antar muka (interface) membran. Oleh karena beberapa jenis ion, yakni ion monovalen dapat masuk melalui membran, perbedaan potensial kimia antara kedua larutan lebih kecil maka memerlukan daya pendorong yang lebih rendah.

Oleh karena itu, tekanan operasi Nano Filtrasi (NF) hanya berkisar antara 7 - 40 bar. Membran NF umumnya dicirikan oleh kemampuan untuk memisahkan jenis ion divalen, umumnya magnesium sulfat $\left(\mathrm{MgSO}_{4}\right)$ atau kalsium klorida $\left(\mathrm{CaCl}_{2}\right)$. Oleh karena terdapat banyak variabilitas di dalam aplikasi NF, retensi $\mathrm{MgSO}_{4}$ umumnya berkisar antara $80 \%$ hingga $98 \%$. Nano-filtrasi umumnya dipilih untuk pemisahan apabila aplikasi reverse osmosis (RO) dan ultrafiltrasi bukanlah pilihan yang tepat. Nanofiltration dapat digunakan untuk aplikasi pemisahan mineral (demineralization), penghilangan warna, dan desalinasi.

\subsubsection{Osmosis Balik (Reverse Osmosis)}

Apabila dua buah larutan dengan konsentarsi encer dan konsentrasi pekat dipisahkan oleh membran semi-permeable, maka larutan dengan konsentrasi yang encer akan terdifusi melalui membran tersebut masuk 
ke dalam larutan yang pekat sampai sampai terjadi kesetimbangan konsentrasi. Fenomena tersebut dikenal sebagai proses osmosis. Jika air tawar dan air asin dipisahkan dengan membran semi-permeable, maka air tawar akan terdifusi ke dalam air asin melalui membran tersebut sampai terjadi kesetimbangan.

Daya pengggerak (driving force) yang menyebabkan terjadinya aliran difusi air tawar ke dalam air asin melalui membran semi-permeable tersebut dinamakan tekanan osomosis. Besarnya tekanan osmosis tersebut tergantung dari karakteristik membran, temperatur air, dan konsentarsi garam yang terlarut dalam air. Tekanan osmotik normal air laut yang mengandung TDS $35.000 \mathrm{ppm}$ dan suhu $25^{\circ} \mathrm{C}$ adalah kira-kira $26,7 \mathrm{~kg} / \mathrm{cm}^{2}$, dan untuk air laut di daerah timur tengah atau laut Merah yang mengandung TDS $42,000 \mathrm{ppm}$, dan suhu $30^{\circ} \mathrm{C}$, tekanan osmotik adalah $32,7 \mathrm{~kg} / \mathrm{m}^{2}$. Apabila pada suatu sistem osmosis tersebut, diberikan tekanan yang lebih besar dari tekanan osmosisnya, maka aliran air tawar akan berbalik yakni dari dari air asin ke air tawar melalui membran semi-permeable, sedangkan garamnya tetap tertinggal di dalam larutan garammya sehingga menjadi lebih pekat. Proses tersebut dinamakan osmosis balik (reverse osmosis).

Keunggulan proses osmosis balik antara lain yakni pengopersianya dilakukan pada suhu kamar, tanpa instalasi pembangkit uap, mudah untuk memperbesar kapasitas, serta pengoperasian alat relatif mudah. Teknologi ini sangat cocok untuk digunakan di wilayah dimana tidak terdapat atau sedikit sekali sumber air tawar misalnya untuk daerah pesisir dan pulaupulau kecil.

\subsection{Pengolahan Air Minum dengan Proses Biofiltrasi dan Ultra Filtrasi}

Dengan menggabungkan proses biofiltrasi seperti yang telah dilakukan pada percobaan di atas dengan teknologi membran ultra filtrasi (UF) maka akan didapatkan suatu alternatif teknologi pengolahan air minum yang dapat menurunkan kandungan zat organik dan amoniak tanpa menggunakan bahan kimia seperti pada proses konvesional. Ilustrasi proses pengolahan air minum dengan kombinasi proses biofiltrasi dan proses ultra filtrasi dapat dilihat seperti pada Gambar 3.

Air baku dari saluran intake dipompa ke reaktor biofilter dengan menggunakan pompa air baku. Reaktor biofilter diisi dengan media biofilter dari bahan plastik tipe sarang tawon. Di dalam reaktor biofilter tersebut senyawa polutan yang ada di dalam air baku misalnya zat organik, amoniak, zat besi, mangan, deterjen dan senyawa polutan lain dapat diuraikan secara biologis. Selain itu padatan tersuspensi yang ada di dalam air baku dapat diendapakan. Air yang keluar dari biofilter selanjutnya di tampung ke bak penampung, selanjutnya dipompa ke mikro filter yang dapat menyaring kontoran sampai 1050 mikron. Dari mikro filter, air dialirkan ke unit ultra filtrasi yang dapat menyaring sampai ukuran 0,01 mikron.

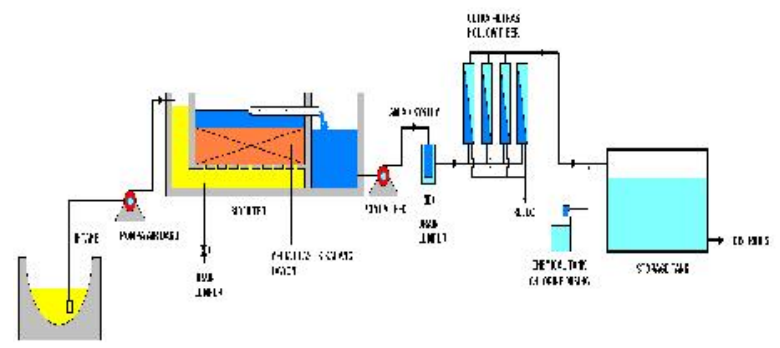

Gambar 3 : llustrasi proses pengolahan air minum dengan kombinasi proses biofilter dan proses filtrasi membrane.

Unit ultra filtrasi menggunakan modul membrane tipe hollow fiber. Air yang keluar dari unit ultra filtrasi dilairkan ke bak penampung air olahan sambil diinjeksi dengan larurtan kaporit untuk proses disinfeksi dan selanjutnya dialirkan ke sistem distribusi. Dengan sistem kombinasi biofiltrasi dan ultra filtrasi mempunyai beberapa kelebihan antara lain adalah :

- Penggunaan proses biofiltrasi dapat menghilangkan senyawa polutan yang tidak bisa dihilangkan dengan proses konvensional misalnya, zat organik, amoniak, deterjen, pestisida, dll. Senyawa tersebut dapat diuraikan dengan proses biologis secara alami (natural).

- Tanpa menggunakan bahan koagulan dan flokulan. Dalam hal ini bahan yang digunakan hanya larutan kaporit untuk mendapatkan konsentrasi sisa klor yang cukup agar tidak terjadi rekontaminasi.

- Dengan proses ultra filtrasi dapat dihasilkan air olahan dengan kualitas yang sangat baik dan stabil.

- Bentuknya lebih kompak sehingga luas area yang dibutuhkan lebih kecil.

- Sangat fleksibel jika ada penambahan kapasitas.

3. PILOT PLAT UNIT PENGOLAHAN AIR SUNGAI MENJADI AIR SIAP MINUM DENGAN PROSES BIOFILTRASI, ULTRAFILTRASI DAN REVERSE OSMOSIS (RO)

\subsection{Fungsi}


Untuk memenuhi kebutuhan air bersih atau air minum bagi masyarakat misalnya pesantren dimana belum terdapat infra struktur penyediaan air bersih.

\subsection{Air Baku Yang Dapat Diolah}

Kategori air yang dapat diolah adalah :

- Air permukaan yang keruh, misalnya air sungai, air danau, air genangan hujan dll.

- Air tanah misalnya air sumur, mata air, air yang mengandung zat besi, mangan, zat kapur, magnesium dll.

Persyaratan air baku adalah sebagai berikut :

- Air baku adalah air tawar atau air payau (TDS maksimum 1000 mg/l).

- Air baku bukan air limbah.

- Air baku tidak tercemar oleh limbah industri atau limbah B3.

\subsection{Kapasitas Alat}

Kapasitas Pengolahan :

Air Siap Minum : 15 liter $/$ menit $=25.000$ liter per hari.

Air Bersih : $125 \mathrm{~m}^{3} /$ hari.

Air Baku : Air sumur atau air tanah, air sungai.

Kualitas air Olahan : Standar DEPKES RI dan dapat langsung diminum, yaitu Keputusan Menteri Kesehatan R.I. No. 907 Tahun 2002 Tentang Syarat-syarat dan Pengawasan Kualitas Air Minum.

\subsection{Proses Pengolahan}

Proses pengolahan yang digunakan adalah kombinasi proses biofiltrasi, ultrafiltrasi dan reverse osmosis. Secara garis besar proses pengolahan yang digunakan dapat dilihat pada Gambar 4 dan gambar 5 (Lampiran).

Air baku yang berasal dari sungai dipompa ke unit reaktor biofiltrasi yang di dalamnya diisi dengan media plastik tipe sarang tawon. Reaktor biofilter diisi dengan media biofilter dari bahan plastik tipe sarang tawon. Dengan adanya media palstik sarang tawon tersebut maka pada permukaan media tersebut akan tumbuh lapisan film mikroorganisme (biofilm) yang akan menguraikan polutan yang ada di dalam air baku. Di dalam reaktor biofilter tersebut senyawa polutan yang ada di dalam air baku misalnya zat organik, amoniak, zat besi, mangan, deterjen dan senyawa polutan lain dapat diuraikan secara biologis. Selain itu padatan tersuspensi yang ada di dalam air baku dapat diendapakan. Air yang keluar dari biofilter selanjutnya di tampung ke bak penampung antara.

Dari bak penampung antara air selanjutnya dipompa ke mikro strainer yang dapat menyaring kotoran padatan sampai 50 mikron sambil diinjeksi dengan larutan kaporit untuk membunuh kuman dan mencegah terjadinya biofouling. Dari mikro strainer air dialirkan ke unit ultra filtrasi yang dapat menyaring sampai ukuran 0,01 mikron. Unit ultra filtrasi menggunakan modul membran tipe hollow fiber. Air yang keluar dari unit ultra filtrasi dialirkan ke bak penampung air bersih dan selanjutnya dialirkan ke sistem distribusi untuk digunakan untuk keperluan air bersih (mandi, cuci, dan lain-lain).

Sebagian dari air bersih hasil olahan proses ultrafiltrasi, selanjutnya diolah untuk menjadi air siap minum. Air dari bak penampung air bersih dipompa ke filter multi media sambil diinjeksi dengan larutan kalium permanganat. Injeksi kalium permanganat berfungsi untuk mengoksidasi zat besi atau mangan yang ada di dalam air serta mengoksidasi zat organik yang ada di dalam air. Selanjutnya zat besi atau mangan yang telah teroksidasi disaring dengan filter multi media yang di dalamnya diisi dengan media mangan zeolit dan karbon aktif.

Filter multi media berfungsi untuk menghilangkkan zat besi dan mangan di dalam air baku yang telah teroksidasi serta untuk menghilangkan bau dan mikro polutan lain yang ada di dalam air. Dari filter multi media, air dialirkan ke filter penukar kation untuk menghilangan kandungan zar kapur dan magnesium yang ada di dalam air. Selanjutnya dialirkan ke unit mikro filter yang dapat menyaring padatan sampai ukuran 1 mikron. Dari unit mikro filter air selanjutnya dialirkan ke unit reverse osmosis (RO),

Unit reverse osmosis (RO) menggunakan modul membrane (tap water membrane) tipe thin film composite. Dengan penyaringan reverse osmosis secara teknis bakteri sudah dapat disaring. Dari unit reverse osmosis, air dialirkan ke unit sterilisator ultraviolet untuk membunuh mikroba yang mungkin belum sempat tersaring oleh membrane RO. Air yang keluar dari unit sterilisator ultra violet adalah air olahan yang siap minum langsung tanpa dimasak dan dapat langsung dibotolkan.

\subsection{Keunggulan}

Dengan sistem kombinasi biofiltrasi dan ultrafiltrasi mempunyai beberapa kelebihan antara lain yakni :

- Penggunaan proses biofiltrasi dapat menghilangkan senyawa polutan yang tidak bisa dihilangkan dengan proses konvensional misalnya, zat organik, amoniak, deterjen, pestisida, dll. Senyawa tersebut dapat diuraikan dengan proses biologis secara alami (natural).

- Tanpa menggunakan bahan koagulan dan flokulan. Dalam hal ini bahan yang 
digunakan hanya larutan kaporit untuk mendapatkan konsentrasi sisa klor yang cukup agar tidak terjadi rekontaminasi.

- Dengan proses ultra filtrasi dapat dihasilkan air olahan dengan kualitas yang sangat baik dan stabil.

- Bentuknya lebih kompak sehingga luas area yang dibutuhkan lebih kecil.

- Sangat fleksibel jika ada penambahan kapasitas.

- Dapat dioperasikan dengan sederhana dan handal, manual flushing dilakukan sesuai kebutuhan dengan indikator pressure gauge.

- Biaya investasi yang ekonomis.

\subsection{Spesifikasi Teknis}

Spesifikasi teknis peralatan unit pengolahan air minum dengan proses biofiltrasi -ultrafiltrasi dan reverse osmosis dengan kapasitas pengolahan air bersih $100 \mathrm{~m}^{3} /$ hari dan air siap minum 15 liter /menit atau sekitar 25.000 liter per hari dapat dilihat pada Tabel 2.

Tabel 2 : Spesifikasi Teknis Peralatan.

1. Pompa Biofiltrasi

$\begin{array}{ll}\text { Tipe } & : \text { Pompa celup/ submersible } \\ \text { Merek } & : \text { HCP Model F-05AF } \\ \text { Kapasitas } & : 0,1-0,22 \mathrm{~m}^{3} / \text { menit } \\ \text { Bahan } & : \text { Polimer atau Stainless steel } \\ \text { Total Head } & : 8-11,5 \mathrm{~m} \\ \text { Listrik } & : 0,5 \mathrm{KW}, 220 \mathrm{~V} \\ \text { Diameter Outlet }: 2 \text { " } \\ \text { Jumlah } & : 1 \text { unit }\end{array}$

2. Reaktor Biofiltrasi

$\begin{array}{ll}\text { Material } & : \text { Figerglass (FRP) } \\ \text { Volume } & : 9000 \text { liter } \\ \text { Waktu Tinggal } & : 2-3 \mathrm{jam} \\ \text { Dimensi Bak } & : 150 \mathrm{~cm} \times 300 \mathrm{~cm} \times 220 \mathrm{~cm} \\ \text { Perlengkapan }: & \text { Bak penenang, ruang lumpur } \\ \text { dan kran penguras lumpur. } & \\ \text { Jumlah } & 1 \text { unit }\end{array}$

3. Media Sarang Tawon

$\begin{array}{ll}\text { Material } & : \text { PVC sheet } \\ \text { Ketebalan } & : 0,15-0,23 \mathrm{~mm} \\ \text { Luas Spsesifik } & : 150-200 \mathrm{~m}^{2} / \mathrm{m}^{3} \\ \text { Diameter lubang } & : 3 \mathrm{~cm} \times 3 \mathrm{~cm} \\ \text { Warna } & : \text { bening transparan. } \\ \text { Porositas Rongga } & : 0,98 \\ \text { Volume media } & : 3,24 \mathrm{~m}^{3}\end{array}$

4. Bak Penampang Antara

$\begin{array}{ll}\text { Volume } & : 5000 \text { liter } \\ \text { Bahan } & : \text { Polyethylene (PE) } \\ \text { Kapasitas } & : 0,1-0,22 \mathrm{~m}^{3} / \text { menit }\end{array}$

Jumlah $: 1$ unit

5. Pompa Feed Ultrafiltrasi

$\begin{array}{ll}\text { Merk } & : \text { CNP } \\ \text { Kapasitas } & : 100-120 \text { liter per menit } \\ \text { Bahan } & : \text { Stainless steel }\end{array}$

$\begin{array}{ll}\text { Head } & : 30 \mathrm{~m} . \text { Tekanan maks : } 3 \text { BAR } \\ \text { Listrik } & : 0,5 \mathrm{KW}, 220 \mathrm{~V} \\ \text { Jumlah } & : 1 \text { unit }\end{array}$

6. Mikro Strainer

Diameter : :8“

Tinggi $\quad: 60 \mathrm{~cm}$

Kapasitas $\quad: 6-8 \mathrm{~m}^{3}$ per jam

Diameter pori : 75 micron

Bahan : Stainless Steel

Jumlah $\quad: 1$ unit

7. Unit Ultra Filtration ( UF )

\begin{tabular}{ll} 
Merek & - \\
Membrane & Hollow Fiber \\
Mateial & Hydrophilic modified Poly \\
\multicolumn{3}{c}{ Acrylonitrile (PAN) } \\
Housing membrane & : Stainless Steel \\
Dimensi membrane & $:$ Dia. 4 "panjang 40 " \\
Derajad Filtrasi & $: 0.10-0.01$ micron \\
Jumlah membrane & $: 10$ unit \\
Back wash & $:$ Otomatis \\
Accessories & $: 4$ buah Solenoid valve \\
& kontrol dengan timer \\
Skid & $:$ Carbon Steel \\
Kapasitas Total & $: 140-180 \mathrm{~m}^{3}$ per hari \\
Jumlah & $: 1$ set
\end{tabular}

$8 \quad$ Pompa Back Wash Ultrafiltrasi

Merek : CNP

Kapasitas : :100-120 liter per menit

Bahan : Stainless steel

Head : $30 \mathrm{~m}$. Tekanan maks : 3 BAR

Listrik : 0,75 KW, $220 \mathrm{~V}$

Jumlah $\quad: 1$ unit

$9 \quad$ Pompa Dosing

Tipe : Chemtech 100/030

Tekanan : 7 Bars

Kapasitas : $4.7 \mathrm{It} /$ hour

Head : SAN

Diafragma : Hypalon

Jumlah : 1 unit

10 Chemical Tank

Volume : 50 liter

Dimensi : ø $50 \mathrm{~cm}, \mathrm{H} 60 \mathrm{~cm}$

Material : Polyethylene (PE)

Jumlah : 1 unit

11 Pompa Feed RO

Merk : Grundfos atau yang setara

Kapasitas : :100-120 liter per menit

Bahan : Stainless steel

Tekanan :4 Bar

Daya : 500 watt, 220 volt

Jumlah : :1 unit

12 Multimedia Filter

Kapasitas : : 4-5 $\mathrm{m}^{3}$ per jam

Bahan : PVC

Dimensi : Dia. 16 ", Tinggi : $120 \mathrm{~cm}$

Tekanan Maks. : 5 Bar

Media : Pasir slika, mangan zeolit dan

Inlet/outlet : 1 "

Jumlah $: 1$ unit 
13 Cartridge Filter

$\begin{array}{ll}\text { Merek } & : \text { Pro Clean } \\ \text { Inlet/outlet } & : 1 \text { " } \\ \text { Kapasitas } & : 4-5 \mathrm{~m}^{3} \text { per jam } \\ \text { Fitration Degree } & : 1 \text { micron } \\ \text { Jumlah } & : 2 \text { unit }\end{array}$

14 Pompa Tekanan Tinggi

Merk : Flint \& Walling F\&W or Equal

Kapasitas : : $4-5 \mathrm{~m}^{3}$ per jam

Bahan : Stainless steel

Tekanan maks : 15 BAR

Motor : 2KW; 220Volt; 50Hz; 2900 RPM

Jumlah $\quad: 1$ unit

15 Unit RO

Model : CF 20T

Kapasitas $\quad: 20 \mathrm{~m}^{3} /$ hari

Tipe Membran : Filmtec BW 4040

Raw Water : Air Payau

Total Dissolved Solid: < 3.000 ppm

Tekanan air masuk : Minimum 1 bar

Tekanan Operasi : $10-20$ bars

Temperatur Operasi : Maximum $40{ }^{\circ} \mathrm{C}$

Toleransi Kadar besi : Maximum $0.01 \mathrm{ppm}$

Toleransi Kadar mangan : Max. 0.01 ppm

Toleransi kadar Khlorin : Max. 0.01 ppm

Tipe elemen : Thin Film Composite

Kelengkapan

- Product Flow meter

- Reject flow meter

- Inlet presure gauge

- Operating presure gauge

- Pre filter pressure gauge

- Reject pressure regulator

Jumlah : 1 unit

- Solenoid valve

16 Ultraviolet Sterilizer

Kapasitas : $: 20 \mathrm{~m}^{3}$ per hari

Bahan :Stainless Steel

Listrik : 40 watt 220 volt

Bahan : Stainless Steel

Jumlah : :1 unit

17 Rangka atau skid

Bahan : Stainless Steel dan Aluminium.

Jumlah $\quad: 1$ unit

Jumlah : :1 set

18 Tangki Penampung

$\begin{array}{ll}\text { Bahan } & : \text { Stainless Steel } \\ \text { Volume } & : 500 \text { liter } \\ \text { Jumlah } & : 2 \text { unit }\end{array}$

19 Perpipaan Sistem (paket)

Jumlah : 1 paket

20 Sistem Automatic Control dan Kelistrikan Box Panel : Mildsteel

Panel Type : Outdoor, relay konvensional

Accessorie : Conductivity meter, selectorswitch, Manual-auto, Volt - Ampere meter

\subsection{Hasil Uji Coba Alat}

\subsubsection{Penyisihan Senyawa Organik}

\section{A. Efisiensi Penyisihan Zat Organik di dalam Reaktor Biofilter}

Setelah proses pembiakan mikroba telah stabil, debit air diatur agar waktu tinggal hidrolis (WTH) di dalam reaktor menjadi 4 (jam), 3 (tiga) jam, 2 (dua) jam dan 1 (satu) jam, untuk mengetahui pengaruhnya terhadap efisiensi penyisihan senyawa organik. Hasil penelitian ditunjukkan seperti pada Gambar 6.

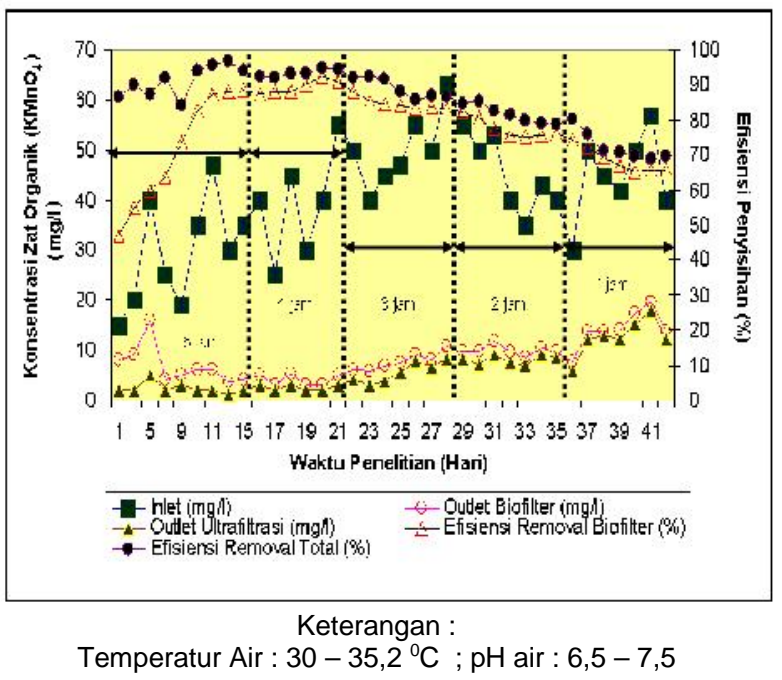

Gambar 6 : Pengaruh Waktu Tinggal Penelitian Terhadap Penurunan Konsentarsi Zat Organik Serta Efisiensi Penyisihan Pada Proses Biofilter

Dari hasil penelitian tersebut terlihat bahwa setelah waktu tinggal diubah menjadi empat jam efisiensi penyisihan zat organik berkisar antara $88 \%$ hingga $90 \%$, dengan ratarata efisiensi $89,53 \%$. Nilai efisiensi yang stabil dicapai 1-2 hari setelah waktu tinggal dirubah. Hasil yang sama juga terjadi setelah waktu tinggal diubah menjadi tiga jam, dua jam dan satu jam, yakni efisiensi penyisihan zat organik turun dan perlahan-lahan efisiensi penyisihan zat organik menjadi stabil setelah 1-2 hari operasi pada setiap WTH. Hal ini disebabkan karena mikro-organisme memerlukan waktu adaptasi terhadap perubahan beban organik yang masuk ke dalam reaktor.

Dari hasil tersebut diketahui bahwa semakin pendek waktu tinggal hidrolis yaitu dari 4 jam menjadi 1 jam, efisiensi rata-rata penyisihan zat organik $\left(\mathrm{KMnO}_{4}\right)$ pada kondisi stabil juga menjadi semakin kecil yakni dari $89,53 \%$ menjadi $68,53 \%$.

Hal ini disebabkan semakin singkatnya waktu kontak antara bahan organik dengan mikroorganisme pada lapisan biofilm, sehingga 
semakin sedikit kesempatan mikroba untuk dapat memanfaatkan zat organik tersebut untuk proses metabolisme tubuhnya.

\section{B. Penyisihan Zat Organik (KMnO4) pada Unit Ultrafiltrasi}

Hasil penelitian penyisihan zat organik dengan Membran Ultrafiltrasi dapat dilihat pada Gambar 7.

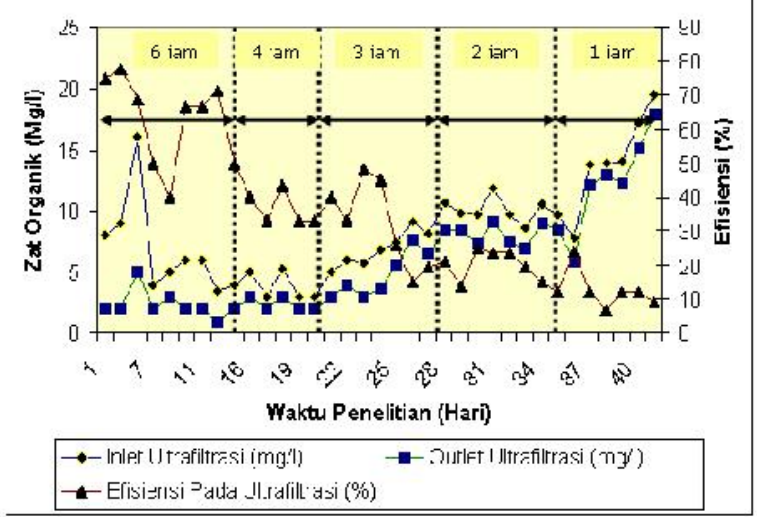

\section{Gambar 7 : Efisiensi Penyisihan Zat Organik Pada Unit Ultrafiltrasi}

Secara teori ultrafiltrasi tidak dapat menyaring zat organik yang terlarut, tetapi dapat memisahkan zat organik yang berada dalam bentuk padatan tersuspensi. Efisiensi penyisihan zat organik di dalam Ultra Filtrasi bervariasi, dan berkisar antara $75 \%$ - 7,1\%. Fluktuasi yang sangat signifikan ini disebabkan karena efisiensi unit ultrafiltrasi hanya dapat menyisihkan zat yang berbentuk padatan, namun jika jika terjadi penyisihan terhadap zat yang bukan padatan hanya berkisar antara 1-2 $\mathrm{mg} / \mathrm{L}$ yang berlangsung stabil, dan juga bergantung pada efisiensi penyisihan pada unit biofilter yang mempengaruhi total efisiensi kedua unit tersebut. Secara umum hasil yang didapat sangat baik, hal ini terlihat dari hasil analisis laboratorium menunjukan konsentrasi zat organik yang diperoleh berkisar antara 2 - 17,82 mg/L, dan itu telah memenuhi standar yang telah ditetapkan sesuai dengan Keputusan Menteri Kesehatan No. 907 tahun 2002 tentang Syarat-Syarat dan Pengawasan Kualitas Air Minum, yang menetapkan kadar maksimum zat organik (KMnO4) yang diizinkan adalah $10 \mathrm{mg} / \mathrm{L}$.

\subsubsection{Penyisihan Senyawa Amoniak}

\section{A. Penyisihan Amonia, Nitrit, dan Nitrat di dalam Reaktor Biofilter}

Setelah proses pembiakan mikroba telah stabil, debit air diatur agar waktu tinggal hidrolis (WTH) di dalam reaktor menjadi 4 (empat) jam, 3 (tiga) jam, 2 (dua) jam dan 1 (satu) jam, untuk mengetahui pengaruhnya terhadap efisiensi penyisihan ammonia, nitrit dan nitrat. Pada waktu tinggal 4 jam dilakukan pengambilan sampel setiap hari selama 6 hari. Pada waktu tinggal 4 jam ini Efisiensi penyisihan amonia turun menjadi $77 \%$ dari $78 \%$ pada hari pertama sampel. Setelah itu efisiensi mulai stabil di hari ke 2 sampai hari ke 6, dengan efisiensi $74-75 \%$.

Pada saat operasi dengan waktu tinggal 3 jam dilakukan pengambilan sampel setiap hari selama 7 hari. Dengan waktu tinggal 3 jam terjadi penurunan efisiensi penyisihan amoniak menjadi $73 \%$ pada hari pertama, dan pada hari berikutnya efisiensi penyisihan amonia stabil pada kisaran 69-70 \%. Untuk waktu tinggal 2 jam dilakukan pengambilan sampel setiap hari selama 7 hari. Pada waktu tinggal 2 jam terjadi penurunan efisiensi amonia menjadi $68 \%$ dan di hari kedua efisiensi turun kembali menjadi $65 \%$, sebelum akhirnya menjadi satbil dengan efisiensi $62 \%$.

Untuk waktu tinggal 1 jam dilakukan pengambilan sampel setiap hari selama 7 hari. Pada waktu tinggal 1 jam terjadi penurunan efisiensi amonia menjadi $61 \%$ pada hari pertama sampel. Pada hari berikutnya efisiensi mulai stabil dengan efisiensi penyisihan sebesar 55\%. Dari hasil penelitian tersebut terlihat bahwa setelah waktu tinggal diubah menjadi empat jam efisiensi penyisihan amonia sekitar $74-75 \%$. Hal yang sama juga terjadi setelah waktu tinggal diubah menjadi tiga jam, dua jam dan satu jam, yakni efisiensi penyisihan amoniak turun sekitar $5-6 \%$, yaitu $69-70 \%$ pada waktu tinggal 3 jam, $62-65 \%$ pada waktu tinggal 2 jam, dan 55\% pada waktu tinggal 1 jam.

Dari penelitian yang telah dilakukan tampak bahwa efisiensi penyisihan amoniak stabil pada hari ke ke 3 - 7 hari operasi, hal ini disebabkan karena mikroba membutuhkan adaptasi setiap terjadi perubahan waktu tinggal. Dari hasil tersebut diketahui bahwa semakin pendek waktu tinggal hidrolis yaitu dari 4 jam menjadi 1 jam, efisiensi penyisihan amonia pada kondisi stabil juga menjadi semakin kecil. Hal ini disebabkan semakin singkatnya waktu kontak antara bahan organik dengan mikroba pada lapisan biofilm,

Hasil Efluen yang dikeluarkan oleh unit biofiltrasi sangat baik karena berada di bawah standar air minum sesuai dengan KepMenkes Nomor 907/Menkes/SK/VII/2002 tentang syaratsyarat dan pengawasan kualitas air minum. Hasil penelitian ditunjukkan seperti pada Gambar 8.

Penurunan konsentrasi amoniak di dalam air menyebabkan konsentrasi nitrit dan nitrat di dalam air olahan menjadi lebih besar. Perubahan konsentrasi Nitrit dan Nitrat sebelum dan sesudah pengolahan ditunjukkan seperti pada 
Gambar 9 dan 10. Peningkatan konsentrasi nitrat disebabkan karena amonia dioksidasi menjadi nitrit, selanjutnya nitrit akan berubah menjadi nitrat.

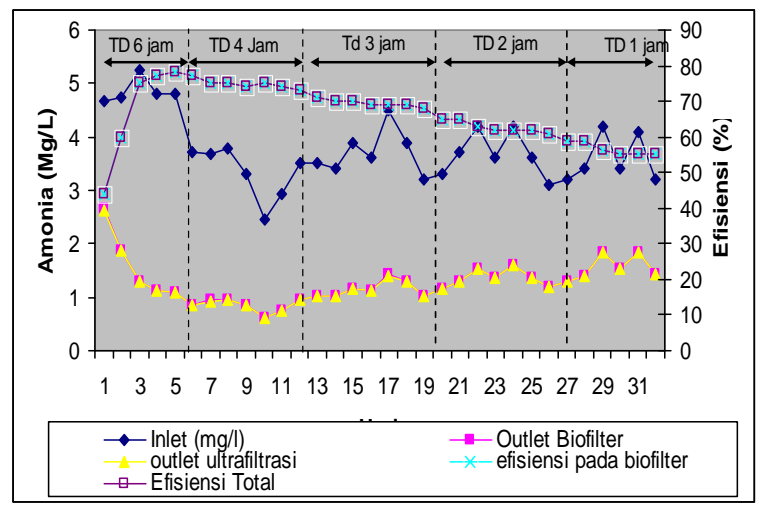

Gambar 8 : Kurva efisiensi penyisihan Amonia

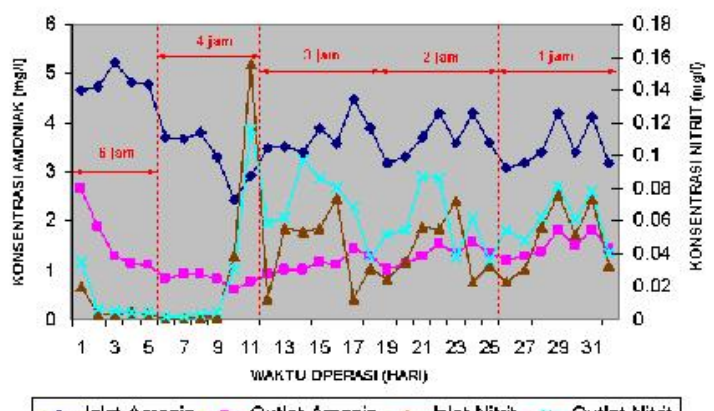

Gambar 9 : Kurva hubungan amonia dan nitrit di dalam Biofilter

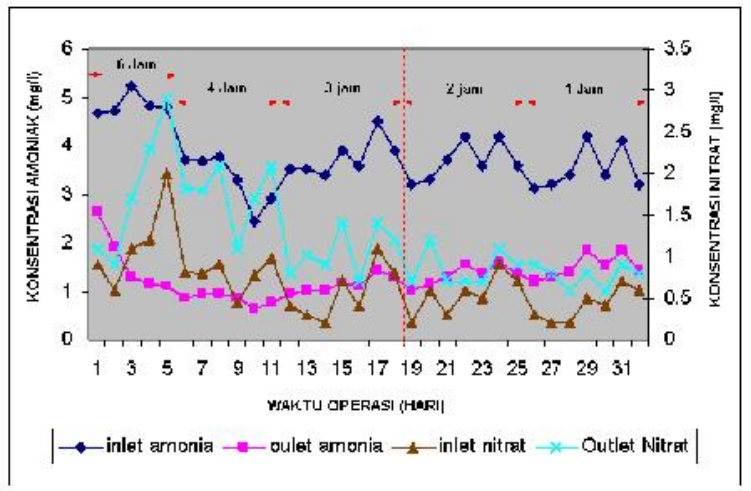

Gambar 10 : Kurva hubungan amonia dan nitrat di dalam Biofilter

Dilihat dari gambar diatas konsentrasi nitrit lebih kecil daripada konsentrasi nitrat hal ini disebabkan karena nitrit ialah senyawa transisi dalam perubahan amonia menjadi nitrat sehingga konsentrasinya meningkat ketika terjadi penurunan amonia. Senyawa ini dihasilkan dari suatu proses oksidasi amonia, tetapi sifatnya tidak stabil karena pada kondisi aerobik selama nitrit terbentuk dengan cepat nitrit dioksidasi menjadi nitrat oleh bakteri nitrobacter, oleh karena itu senyawa nitrit ditemukan dalam jumlah yang kecil.

Peningkatan konsentrasi nitrat dapat disebabkan adanya oksigen yang dialiri secara terus menerus ke dalam reaktor, sehingga dapat menyebabkan pembentukan nitrat, seperti reaksi dibawah ini :

$$
\begin{aligned}
& \mathrm{NO}_{2}^{-}+1 / 2 \mathrm{O}_{2} \Rightarrow \mathrm{NO}_{3}^{--} \\
& \mathrm{NH}_{4}^{+}+2 \mathrm{O}_{2} \Rightarrow \mathrm{NO}_{3}^{--}+2 \mathrm{H}^{+}+\mathrm{H}_{2} \mathrm{O}
\end{aligned}
$$

Dilihat dari penurunan konsentrasi amoniak dan peningkatan konsentrasi nitrat menunjukkan bahwa di dalam biofilter terjadi proses nitrifikasi. Bakteria yang terlibat dalam proses ini adalah bakteri autotrof yang berperan dalam proses nitrifikasi, sedangkan bakteri heterotrof berperan dalam penguraian beban organik. Walaupun bakteri autotrof berperan dalam proses nitrifikasi, proses ini dapat juga terjadi dengan adanya bakteri heterotrof. Bakteri heterotrof menggunakan substrat organik sebagai sumber energinya, sedangkan bakteri autotrof menggunakan senyawa $\mathrm{CO}_{2}$ dan $\mathrm{HCO}_{3}-$ sebagai sumber energi yang diperoleh dari hasil oksidasi bakteri heterotrof ${ }^{10)}$.

Proses nitrifikasi yang terjadi adalah suatu proses konversi dari amonia menjadi nitrit yang kemudian menjadi nitrat yang dilakukan oleh bakteri autotropik dan heterotropik 5). Pengubahan amonia menjadi nitrit dilakukan oleh bakteri nitrosomonas dan selanjutnya nitrit yang terbentuk diubah menjadi nitrat oleh bakteri nitrobacter. Proses nitrifikasi oleh kedua jenis bakteri di atas berlangsung dalam keadaan aerob sehingga memerlukan konsentrasi oksigen yang cukup untuk sumber energi dalam menunjang proses metabolisme, dan juga proses nitrifikasi merupakan suatu proses aerob sehingga keberadaan oksigen sangat penting dalam proses ini 2). Kebutuhan oksigen dinyatakan yang dalam Konsentrasi DO jsangat penting bagi nitrifikasi, sehingga oksigen harus di distribusikan dengan baik ke dalam reaktor dan tidak boleh kurang dari $2 \mathrm{mg} / \mathrm{l}^{4)}$. Dari penelitian yang dilakukan kadar oksigen tersuplai dengan baik dengan konsentrasi DO di biofilter rata-rata $5,3 \mathrm{mg} / \mathrm{l}$ dan di outlet ultrafiltrasi $5,1 \mathrm{mg} / \mathrm{l}$.

Pada proses nitrifikasi $\mathrm{pH}$ optimum yang diinginkan adalah 7,2 - 7,8. $\mathrm{pH}$ yang berkisar 7,2 - 7,8 sangat bagus bagi petumbuhan bakteri Nitrobacter ${ }^{4)}$. Dari penelitian diketahui terjadi penurunan $\mathrm{pH}$ karena dihasilkannya $\mathrm{H}^{+}$pada proses nitrifikasi, namun $\mathrm{pH}$ efluen yang dihasilkan di unit biofilter masih terdapat dalam entang $\mathrm{pH}$ yang sesuai bagi nitrifikasi, yaitu rata- 
rata 7-7,5. Dan suhu yang dibutuhkan untuk bakteri nitrifer berkisar antara $8-30^{\circ} \mathrm{C}$, dan untuk optimum suhu yan diperlukan adalah sekitar $30^{\circ}$ C 4) Dari data yang di dapat suhu di reaktor biofiltrasi berkisar antara $29-30^{\circ} \mathrm{C}$, Ini merupakan suhu yang optimum bagi proses nitrifikasi. Sedangkan di unit ultrafiltrasi tidak terjadi penurunan atau kenaikan suhu.

\section{B. Penyisihan Amonia, Nitrit dan Nitrat Unit Ultrafiltrasi}

Membran ultrafiltrasi ialah teknologi untuk menyaring padatan tersuspensi. Dimana unit ini dapat menyaring sampai 0,01 mikron, sehingga senyawa yang terlarut dan senyawa yang ukuran partikelnya kurang dari 0,01 mikron tidak dapat tersaring. Hasil penelitian ditunjukkan seperti pada dan Gambar 11.

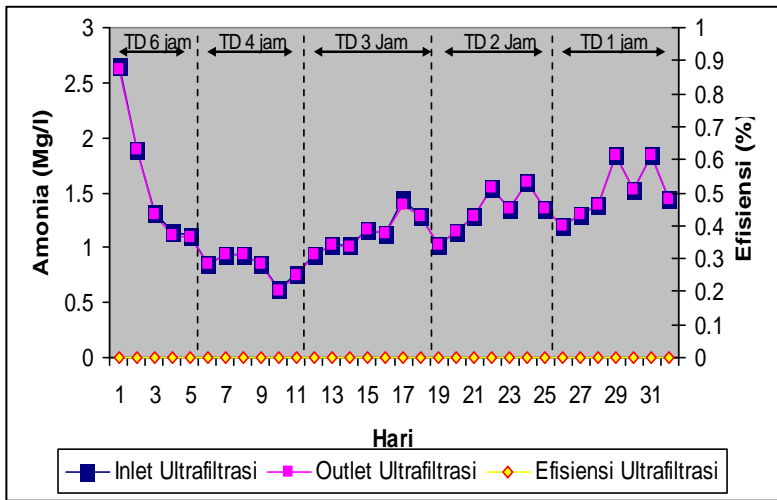

Gambar 11 : kurva Efisiensi penyisihan amonia pada ultrafiltrasi

Dari hasil terlihat bahwa tidak terjadi penurunan konsentrasi ammonia, nitrit, dan nitrat hal ini disebabkan karena amonia bukan merupakan padatan, tetapi merupakan senyawa yang terlarut. Dan hal ini juga disebabkan oleh senyawa amonia, Nitrit, Nitrat menempel pada padatan sehinnga ikut tersaring bersama padatan. Hal ini dapat dilihat dari Gambar 11 dimana jumlah konsentrasi amonia di inlet unit ultrafiltrasi sama dengan di outlet unit ultrafiltrasi.

\subsubsection{Penyisihan Zat Besi (Fe)}

\section{A. Efisiensi Penyisihan Besi (Fe) di dalam Reaktor Biofilter}

Berdasarkan hasil percobaan tersebut di atas dengan menggunakan proses biofilter dengan media plastik tipe sarang tawon dapat juga menghilangkan besi yang ada di ada air dengan cukup baik. Konsentrasi zat besi yang ada di dalam air sungai selama percobaan berkisar antara $0,428 \mathrm{mg}$ per liter sampai dengan 0,833 mg per liter. Pengaruh waktu tinggal hidrolik (WTH) terhadap penurunan konsentarsi zat besi selama percobaan secara lengkap ditunjukkan seperti pada Gambar 12.

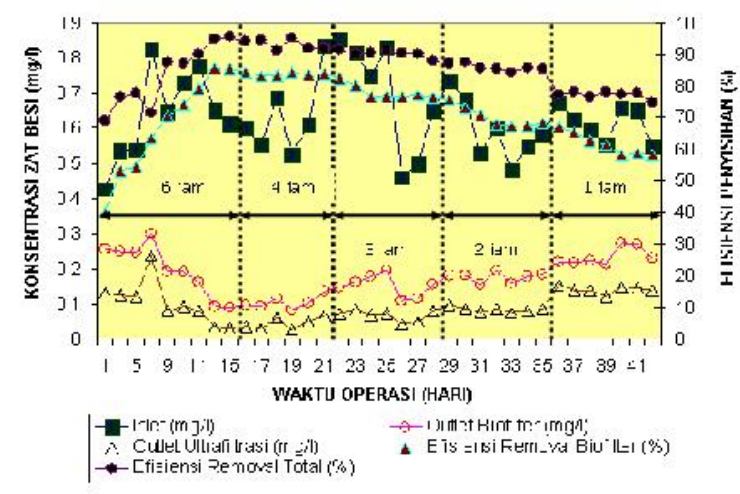

Keterangan :Temperatur Air : $30-35,2^{\circ} \mathrm{C} ; \mathrm{pH}$ air : $6,5-7,5$

Gambar 12 : Grafik Konsentrasi Zat Besi

Sebelum Dan Sesudah Pengolahan Serta Efisiensi Penyisihan

Secara umum semakin kecil waktu tinggal hidrolik di dalam reaktor maka efisiensi penyisihan besi juga semakin kecil. Dengan waktu tinggal hidrolik (WTH) 4 jam efisiensi penyisihan zat besik berkisar antara 83,33 $84,27 \%$, untuk WTH 3 jam efisiensi penyisihan berkisar antara 76,23 - 77,25 \%, untuk WTH 2 jam efisiensi penyisihan 67,34 - 70,75 \%, sedangkan untuk WTH 1 jam efisiensi penyisihan zat besi berkisar antara 58,35 $62,78 \%$.

\section{B. Efisiensi Penyisihan Besi (Fe) Unit Ultrafiltrasi}

Secara teori ultrafiltrasi hanya dapat menyisihkan zat yang berbentuk padatan sampai ukuran 0.01 mikron, Secara teori penyisihan dari unit ultrafiltrasi hanya dapat menyisihkan zat yang berbentuk padatan bukan yang terlarut. Secara keseluruhan proses penyisihan pada unit ultrafiltrasi bergantung kepada penyisihan yang terjadi di unit biofilter. Hasil penelitian menunjukan konsentrasi besi (Fe) di dalam air olahan yang diperoleh berkisar antara 0,24$0,028 \mathrm{mg} / \mathrm{L}$, dan itu telah jauh dibawah standar yang telah ditetapkan oleh Keputusan Menteri Kesehatan No. 907 tahun 2002 tentang SyaratSyarat dan Pengawasan Kualitas Air Minum, yang menetapkan kadar maksimum besi (Fe) yang di izinkan adalah 0,3 $\mathrm{mg} / \mathrm{L}$. Efisiensi Penyisihan Besi (Fe) pada unit Ultrafiltrasi dapat dilihat pada Gambar 13. 


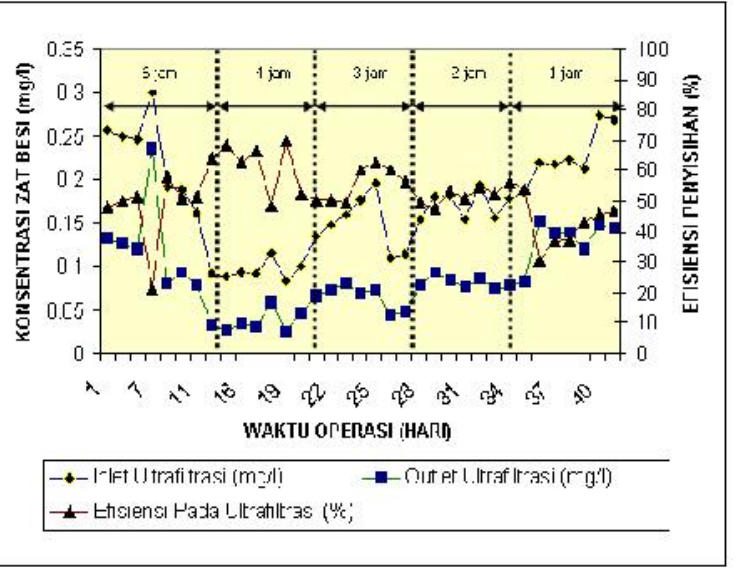

Gambar 13 : Efisiensi Penyisihan Besi (Fe) Pada Unit Ultrafiltrasi

\subsubsection{Penyisihan Mangan (Mn)}

\section{A. Efisiensi Penyisihan Mangan (Mn) di dalam Reaktor Biofilter}

Berdasarkan hasil percobaan tersebut di atas dengan menggunakan proses biofilter dengan media plastik tipe sarang tawon dapat juga menghilangkan mangan yang ada di ada air baku dengan cukup baik. Konsentrasi mangan yang ada di dalam air sungai selama percobaan berkisar antara $0,312 \mathrm{mg}$ per liter sampai dengan $0,923 \mathrm{mg}$ per liter. Pengaruh waktu tinggal hidrolik (WTH) terhadap penurunan konsentarsi mangan selama percobaan secara lengkap ditunjukkan seperti pada Gambar 14.

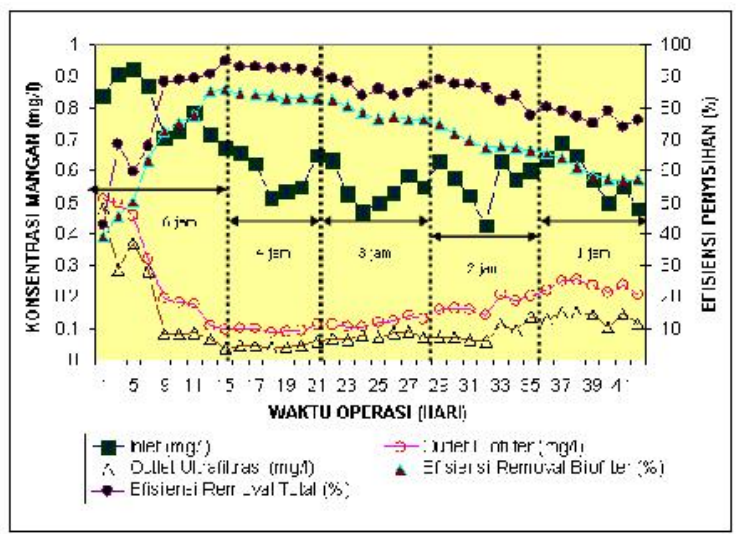

Keterangan :Temperatur Air : $30-35,2^{\circ} \mathrm{C} ; \mathrm{pH}$ air :

$$
6,5-7,5
$$

Grafik 14 : Grafik Konsentrasi Mangan Sebelum Dan Sesudah Pengolahan Serta Efisiensi Penyisihan

Secara umum semakin kecil waktu tinggal hidrolik di dalam reaktor maka efisiensi penyisihan mangan juga semakin kecil. Dengan waktu tinggal hidrolik (WTH) 4 jam efisiensi penyisihan zat besik berkisar antara 83,25-84,69
$\%$, untuk WTH 3 jam efisiensi penyisihan berkisar antara 76,25-78,54\%, untuk WTH 2 jam efisiensi penyisihan $66.33-69.54 \%$, sedangkan untuk WTH 1 jam efisiensi penyisihan zat besi berkisar antara 57,25-61,35\%.

\section{B. Penyisihan Mangan (Mn) Unit Ultrafiltrasi}

Efisiensi Penyisihan Mangan (Mn) di dalam unit ultrafiltrasi dapat dilihat pada Gambar 15. Dari hasil tersebut dapat dilihat bahwa efisiensi penyisihan mangan di unit Ultrafiltrasi berkisar antara 11,88 - 64,95\%. Secara keseluruhan proses penyisihan pada unit ultrafiltrasi bergantung kepada penyisihan yang terjadi di unit biofilter.

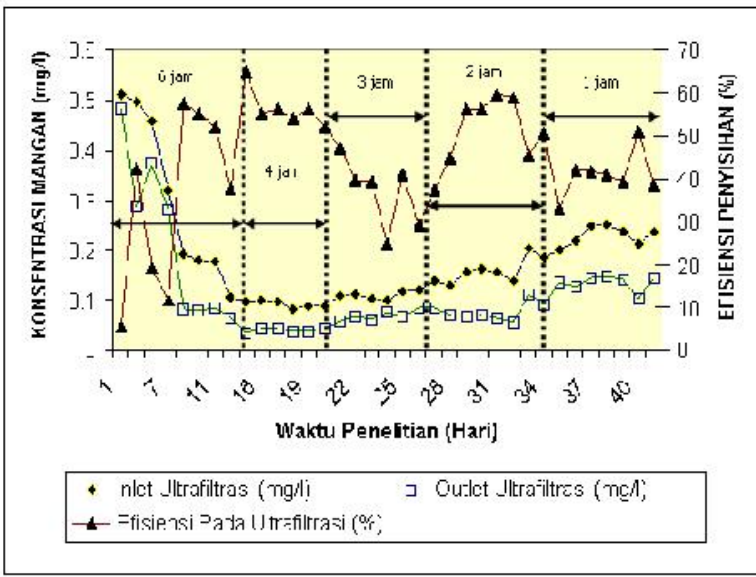

Gambar 15 : Efisiensi Penyisihan Mangan (Mn) Pada Unit Ultrafiltrasi

Secara umum dengan waktu tinggal 2 jam di dalam reaktor biofilter konsentrasi mangan di dalam air olahan telah dibawah $0,1 \mathrm{mg} / \mathrm{l}$, dan hal ini telah memenuhi standar yang telah ditetapkan oleh Keputusan Menteri Kesehatan No. 907 tahun 2002 tentang Syarat-Syarat dan Pengawasan Kualitas Air Minum, yang menetapkan kadar maksimum mangan (Mn) yang di izinkan adalah $0,1 \mathrm{Mg} / 1$.

\subsubsection{Penyisihan TSS}

\section{A. Pengaruh Waktu Tinggal Terhadap Efisiensi Total Suspended Solid (TSS)}

Total padatan tersuspensi adalah bahanbahan tersuspensi (diameter $>1 \mathrm{~m}$ ) yang tertahan pada saringan millipore dengan diameter pori $0,45-1,58 \mathrm{~m}$. TSS terdiri atas lumpur dan pasir halus serta jasad-jasad renik terutama yang disebabkan oleh kikisan tanah atau erosi yang terbawa ke dalam badan air. Masuknya padatan tersuspensi ke dalam perairan dapat menimbulkan kekeruhan air. 
Padatan tersuspensi yang tinggi akan mempengaruhi air karena, menghalangi dan mengurangi penentrasi cahaya kedalam badan air. Kondisi ini akan mengurangi pasokan oksigen terlarut dalam badan air. padatan tersuspensi akan mengurangi penetrasi cahaya ke dalam air, sehingga mempengaruhi regenerasi oksigen dan kekeruhan air juga semakin meningkat.

Hasil analisis laboratorium yang dilakukan menunjukan bahwa outlet yang diperoleh dari setiap sampel yang diambil pada setiap variasi waktu tinggal yang dilakukan, dapat dilihat bahwa semakin kecil waktu tingga di dalam biofilter efisiensi penurunan TSS semakin kecil. Hasil analisis laboratorium secara lengkap dapat dilihat pada Gambar 16.

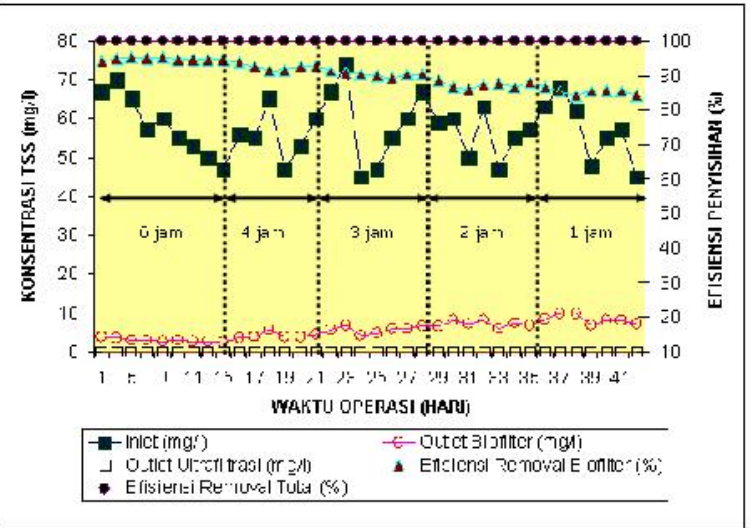

Keterangan : Temperatur Air : $30-35.2^{\circ} \mathrm{C} ; \mathrm{pH}$ air : $6.5-7.5$

Gambar 16 : Grafik Konsentrasi Total Suspended Solid (TSS) Sebelum Dan Sesudah

Pengolahan Serta Efisiensi Penyisihan

Dari grafik di atas dapat dilihat bahwa proses penyisihan suspended solid pada reaktor biofilter dipengaruhi oleh waktu tinggal hidrolis. Penurunan konsentrasi TSS disebabkan oleh karena suspended solid mengendap dan menempel pada media biofilter, tanpa dipengaruhi oleh aktivitas penyisihan oleh mikroba yang terdapat pada media tersebut.

\section{B. Pengaruh Membran Ultrafiltrasi Terhadap Penyisihan Total Suspended Solid (TSS)}

Total Suspended Solid (TSS) atau suspended solid merupakan padatan yang bervariasi dari yang berbentuk kasar hingga yang berbentuk koloid, dalam penelitian ini air baku diambil langsung dari sungai, sehingga kemungkinan padatan berasal dari sedimen yang terdapat dipinggir sungai, seperti tanah, pasir, dan lain-lain. Ukuran dari Total Suspended Solid (TSS) biasanya berkisar antara 0,45 - 1,58 m. Maka dari itu dengan kemampuan dari unit ultrafiltrasi yang mampu menyaring hingga mencapai senyawa yang berukuran $0.01 \mathrm{~m}$, maka Total Suspended Solid (TSS) yang terdapat dalam air baku penelitian dapat tersaring dengan sempurna, dan hal tersebut dibuktikan dengan hasil penelitian yang dilakukan pada unit ultrafiltrasi yang mencapai nilai efisiensi $100 \%$. Dari hasil penelitian tersebut, maka air hasil pengolahan unit ultrafiltrasi telah sesuai dengan baku mutu air minum. Efisiensi Penyisihan Total Suspended Solid (TSS) Pada Unit Ultrafiltrasi dapat dilihat pada Gambar 17.

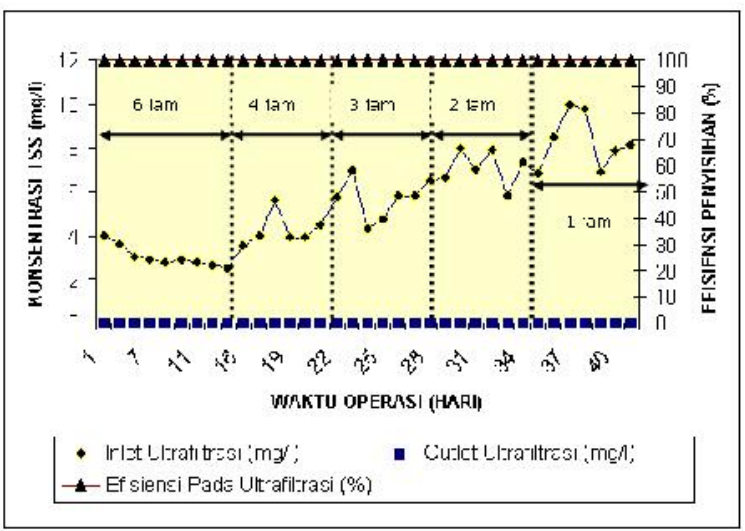

Gambar 17 : Efisiensi Penyisihan Total Suspended Solid (TSS) Pada Unit Ultrafiltrasi

\subsubsection{Hasil Uji Coba Biofiltrasi-Ultrafiltrasi- Reverse Osmosis (RO)}

Hasil uji coba pengolahan air dengan proses biofiltrasi, ultra filtrasi dan reverse osmosis dengan air baku air sungai dapat dihasilkan air olahan dengan kualitas yang sangat baik (air siap minum), tanpa menggunakan bahan kimia. Hasil analisa kualitas air sebelum dan sesudah proses pengolahan dapat dilihat pada Tabel 3 (LAMPIRAN). Biaya pengolahan air bersih dengan proses biofiltrasi dan ultrafiltrasi adalah sekitar Rp.500,- per $\mathrm{m}^{3}$. Biaya tersebut hanya untuk biaya listrik dan bahan kimia dan belum termasuk biaya operator).

\section{KESIMPULAN}

Dari hasil kegiatan dapat disimpulkan bahwa :

- Semakin kecil waktu tinggal hidrolis (WTH), efisiesi penghilangan zat organik semakin kecil. Dengan kondisi waktu tinggal hidrolis 1 jam efisiensi penghilangan zat organik 30,92 $\%$ untuk waktu tinggal 2 jam efisiensi sebesar $45,70 \%$ sedangkan pada waktu tinggal 3 jam 
sebesar 53,89\% dan pada waktu tinggal 4 jam sebesar 64,27\%.

- Dengan kondisi waktu tinggal hidrolis 1 jam efisiensi penghilangan zat organik 30,92\% untuk waktu tinggal 2 jam efisiensi sebesar $45,70 \%$ sedangkan pada waktu tinggal 3 jam sebesar 53,89\% dan pada waktu tinggal 4 jam sebesar 64,27\%.

- Dengan beban organik antara 0,2 - 1,5 $\mathrm{kg} / \mathrm{m}^{3}$.hari, hubungan antara beban organik dengan efisiensi penghilangan organik menunjukkan hubungan yang linier dengan persamaan $Y=27,193 X+66,866$, dimana :

$\mathrm{Y}=$ Efisiensi penghilangan senayawa

Organik (\%).

$X=$ Beban organik ( $\mathrm{kg} / \mathrm{m}^{3}$ media.hari).

- Efisiensi penurunan amoniak berdasarkan variasi waktu tinggal hidrolis 1-3 jam berkisar antara 48,74 \% - 73,59 \%. Pada pengolahan dengan pengkondisian waktu tinggal hidrolis 1 jam efisiensi penurunan sebesar 48,74\%, untuk waktu tinggal 2 jam menunjukkan efisiensi sebesar $67,98 \%$, untuk waktu tinggal 3 jam efisiensi sebesar 73,59\%.

- Pengolahan pendahuluan dengan proses biofiltrasi pada kondisi waktu tinggal hidrolik (WTH) 1-4 jam, konsentrasi zat besi dapat diturunkan dengan efisensi penghilangan berkisar antara $20 \%$ sampai dengan $74 \%$.

- Dengan sistem kombinasi biofiltrasi dan ultra filtrasi mempunyai beberapa kelebihan antara lain penggunaan proses biofiltrasi dapat menghilangkan senyawa polutan yang tidak bisa dihilangkan dengan proses konvensional misalnya zat organik, amoniak, deterjen, pestisida, dll. Senyawa tersebut dapat diuraikan dengan proses biologis secara alami (natural).

- Dengan kombinasi proses biofiltrasi dan ultra filtrasi, pengolahan air minum dapat dilakukan tanpa menggunakan bahan koagulan dan flokulan. Dalam hal ini bahan yang digunakan hanya larutan kaporit untuk mendapatkan konsentrasi sisa khlor yang cukup agar tidak terjadi rekontaminasi.

- Pengolahan air bersih dengan proses Ultrafiltrasi sangat efektif untuk menghilangkan kekeruhan air baku.

- Pengolahan air dengan proses Ultrafiltrasi tidak dapat digunakan untuk menghilangkan atau menurunkan konsentrasi TDS (total disolved solids), artinya tidak dapat digunakan untuk mengolah air asin menjadi air minum.

- Kombinasi proses ultrafiltrasi dan reverse osmosis (RO) dapat digunakan untuk mengolah air sungai atau air irigasi menjadi air siap minum dengan kualitas yang sanggat baik dengan biaya relatif murah.

- Proses pengoperasian peralatan mudah dan dapat dioperasikan oleh operator dengan tingkat pendidikan yang relatif rendah.

\section{DAFTAR PUSTAKA}

1. Anonim : Peraturan Menteri Kesehatan Nomor 907/Menkes/SK/VII/2002 tentang syarat-syarat dan pengawasan kualitas air minum.

2. Benefield, Larry D. (1980). Biological Process Design for Wastewater Treatment. United States of America: Prentice-Hall, Inc.

3. Bergman, R.A. 2005. Membrane Processes. In : Water Treatment Plant Design, $4^{\text {Th }}$ edition. New York, McGraw-Hill.

4. Bitton G. (1994), "Wastewater Microbiology". Wiley-Liss, New York.

5. Grady, C.P.L and Lim, H.C.(1980). "Biological Wastewater Treatment", Marcel Dekker Inc. New York.

6. Hikami, Sumiko (1992), "Shinseki rosohou ni yoru mizu shouri gijutsu (Water Treatment with Submerged Filter)", Kougyou Yousui No.411, 12,1992.

7. Horan, N.J.(1990). "Biological Wastewater Treatment systems : Theory and Operation". University of Leeds, England. John Wiley \& Sons Ltd.

8. JICA:" Water Supply Engineering VOL.I ", Edited By Japan Water works Association.

9. Lin , Shun Dar (2007). Water and Wastewater Calculation Manual. second edition. Mc Graw-Hill Companies, New York.

10. Metclaf And Eddy (1991), "Waste Water Engineering", Mc Graw Hill.

11. Winkler, M.A. 1981. Biological Treatment of Wastewater. John Willey and Sons, New York. 


\section{LAMPIRAN :}

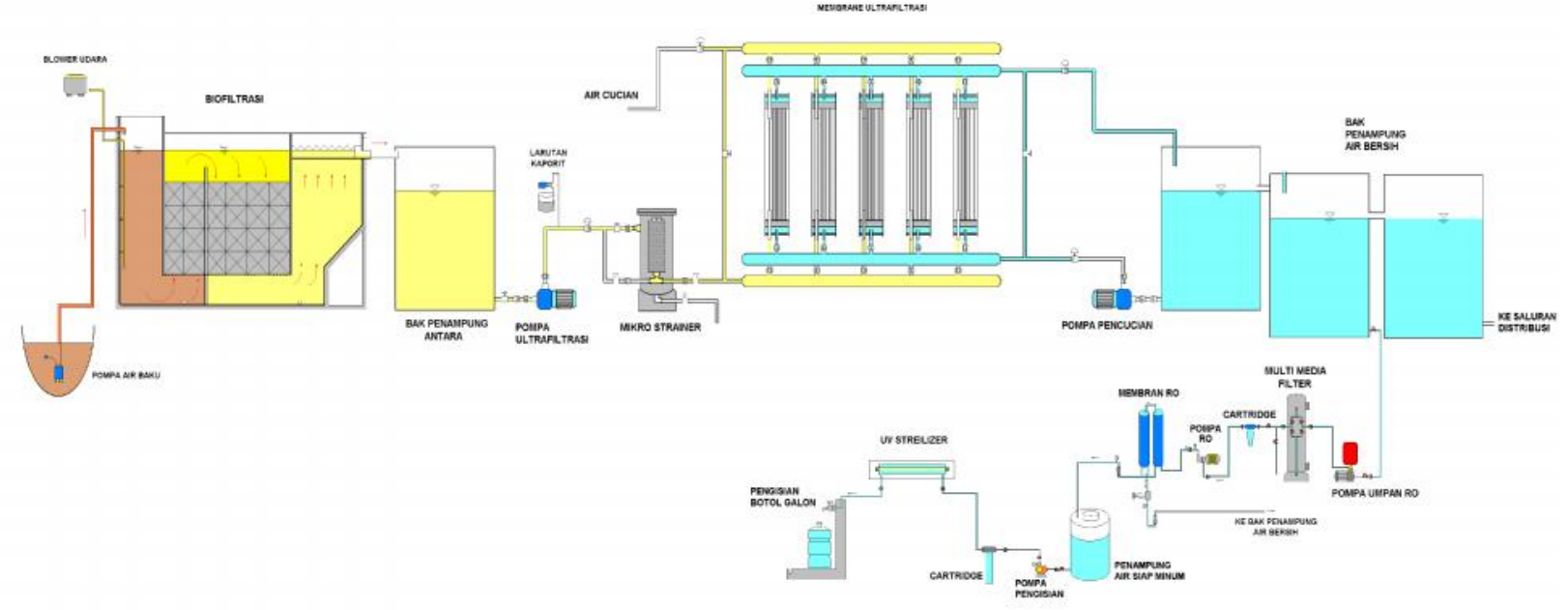

Gambar 4 : Diagram Pengolahan Air Siap Minum Dengan Kombinasi Proses Biofiltrasi, Ultrafiltrasi Dan Reverse Osmosis.

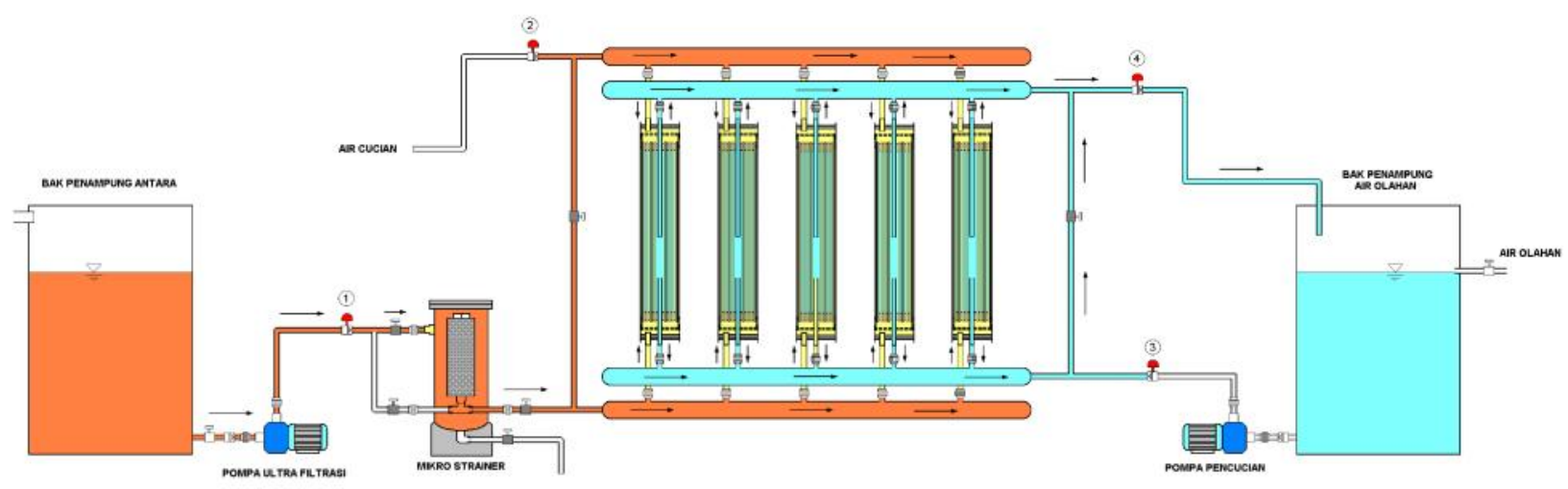

Proses Penyaringan pada Unit Ultrafiltrasi.

Solenoid Valve 1 \& 4 Buka; Solenoid Valve 2 \& 3 Tutup

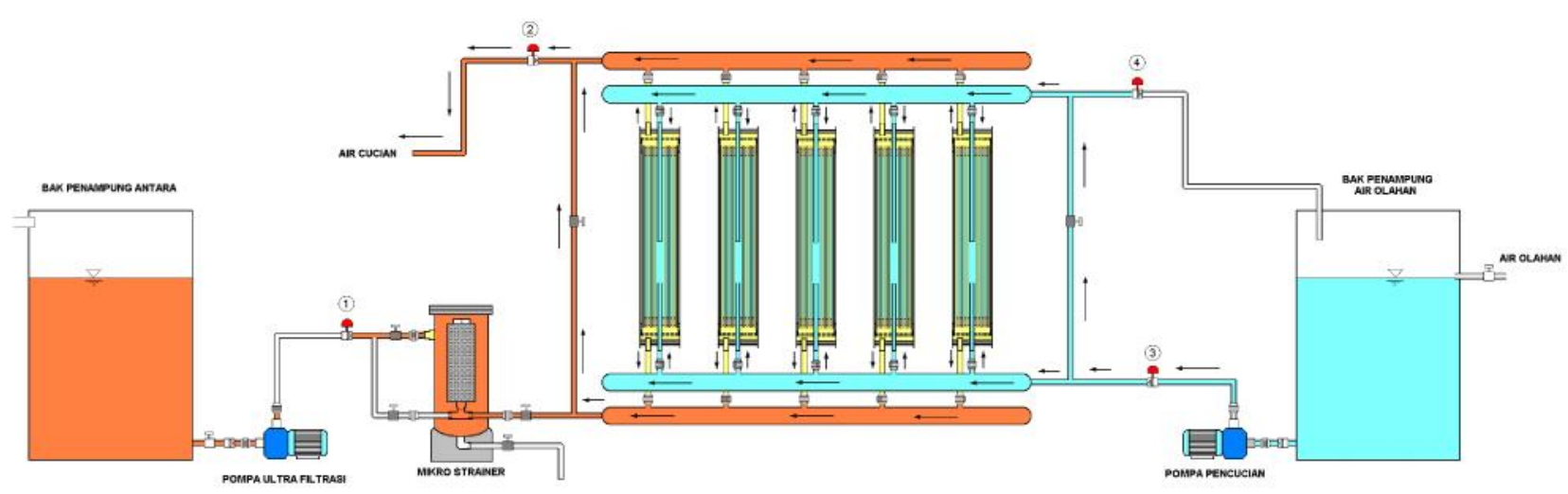

Proses Pencucian Balik pada Unit Ultrafiltrasi.

Solenoid Valve 1 \& 4 Tutup ; Solenoid Valve 2 \& 3 Buka.

Gambar 5 : Skema Proses Penyaringan Dan Pencucian Balik Pada Unit Ultrafiltrasi. 


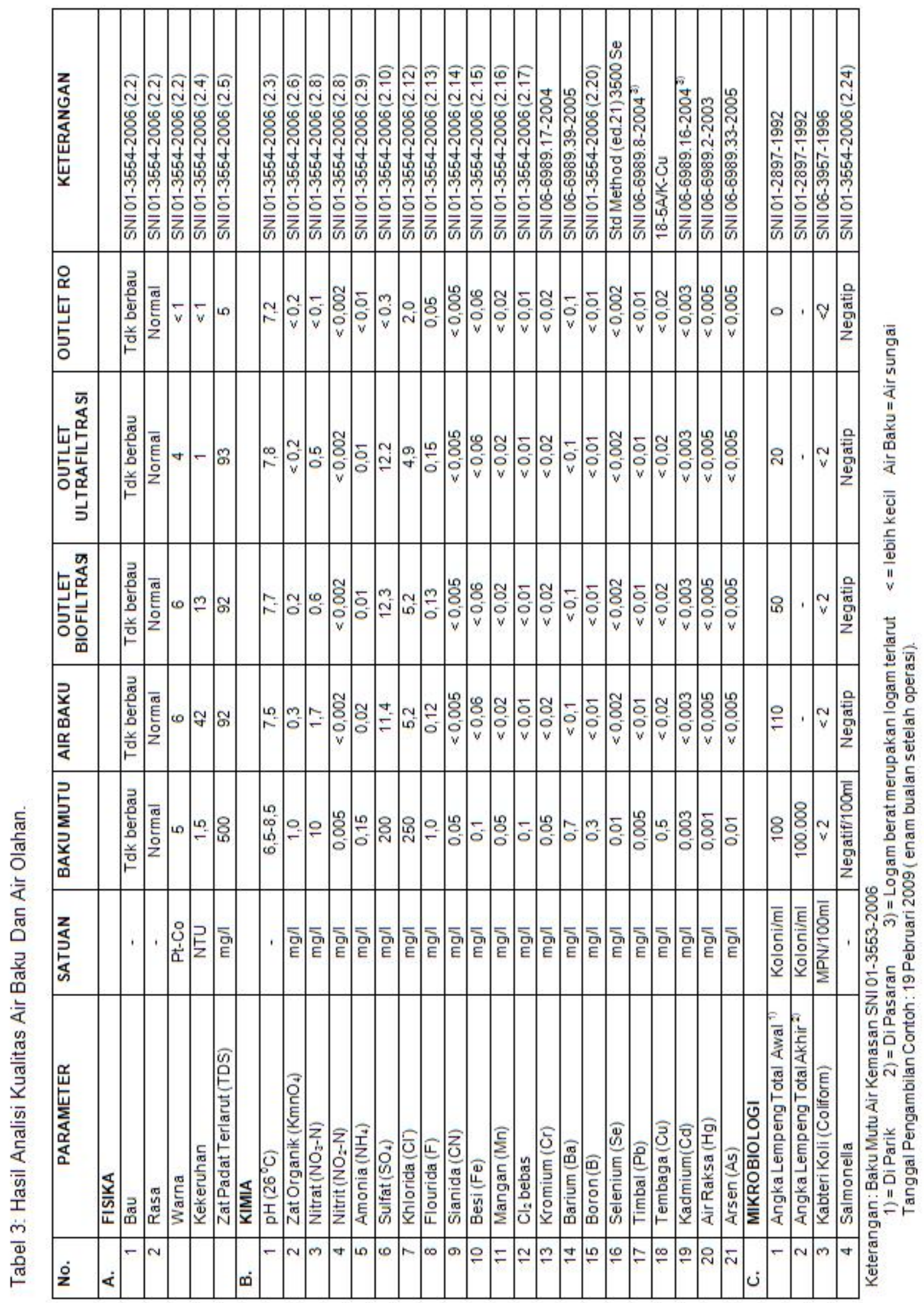




\section{FOTO PERALATAN}

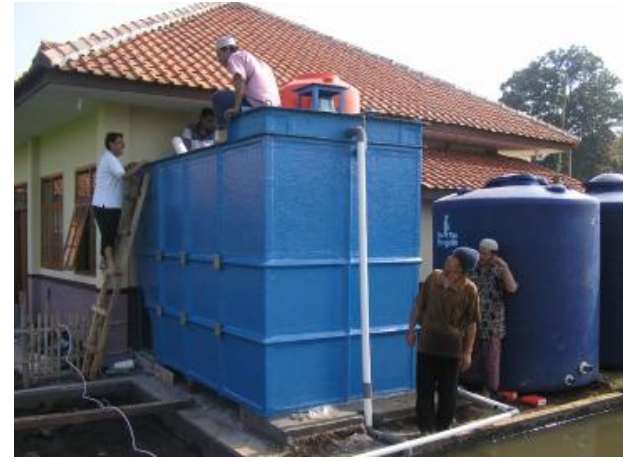

Gambar : Reaktor Biofiltrasi Dengan Media Plastik Sarang Tawon.
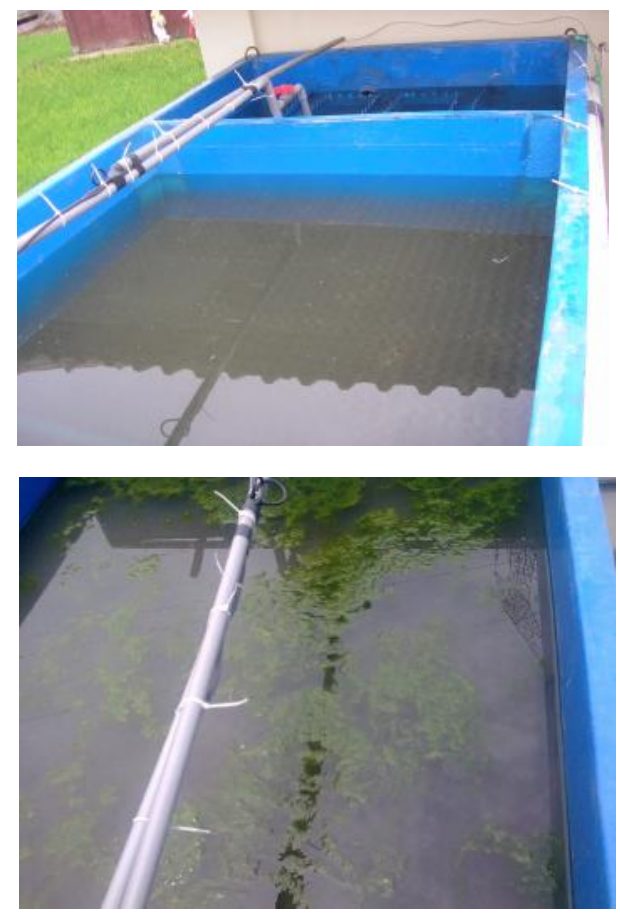

Gambar : Media Plastik Sarang Tawon Di Dalam Reaktor Biofilter.

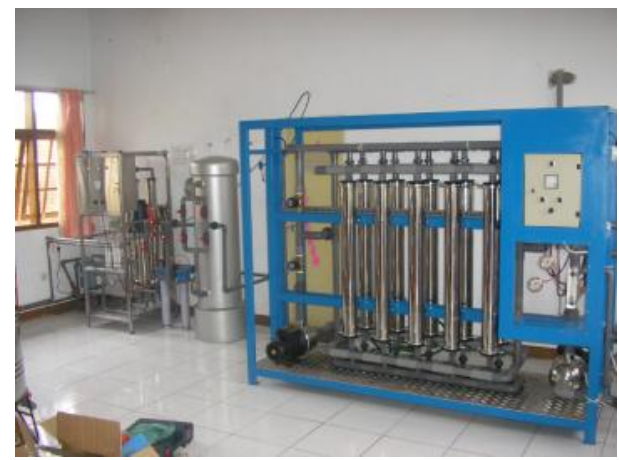

Gambar : Unit Ultrafiltrasi Terpasang.

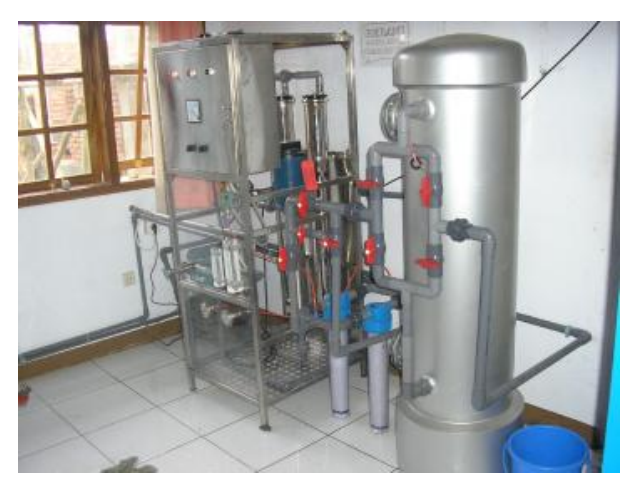

Gambar : Unit Reverse Osmosis (RO) Terpasang.

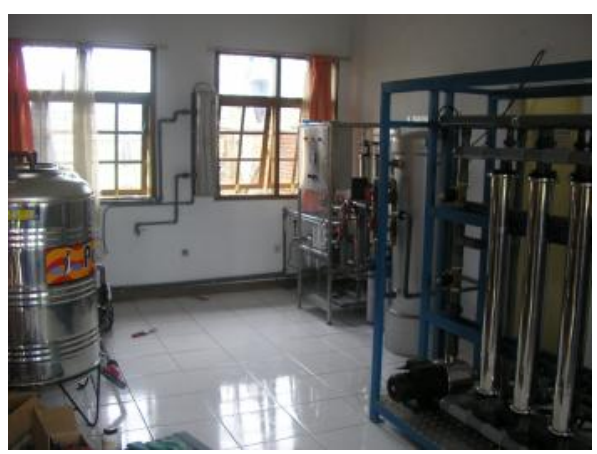

Sterilizer Ultraviolet.

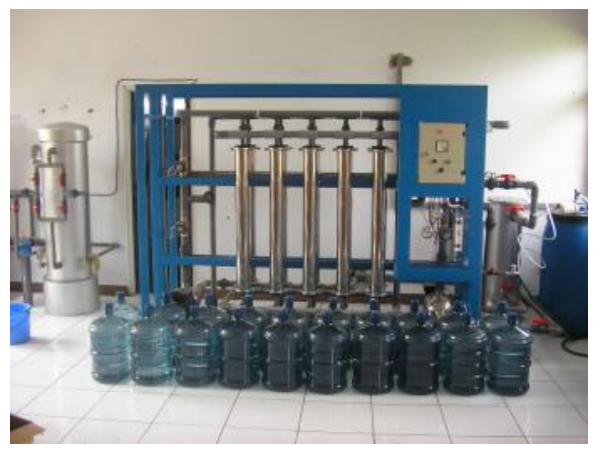

Gambar : Produk Air Siap Minum Dalam Botol Galon.

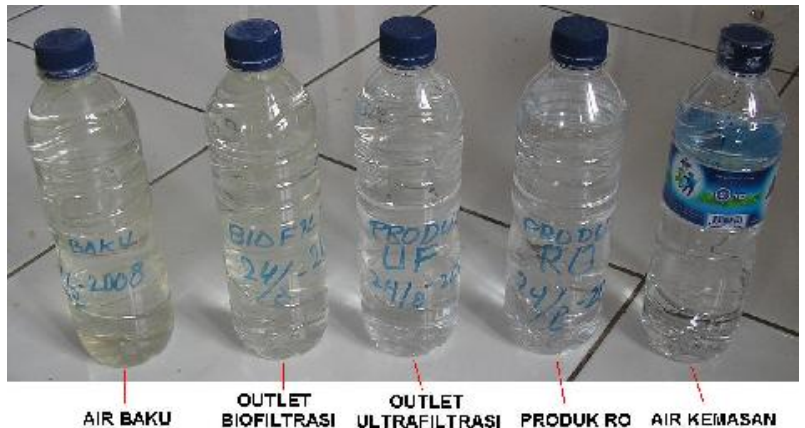

Gambar : Air baku dan air olahan. 